\title{
CEO Inside Debt and Corporate Debt Maturity Structure
}

DOI:

10.1016/j.jbankfin.2016.05.009

\section{Document Version}

Accepted author manuscript

Link to publication record in Manchester Research Explorer

\section{Citation for published version (APA):}

Dang, V., \& Phan, H. V. (2016). CEO Inside Debt and Corporate Debt Maturity Structure. Journal of Banking \& Finance, 70, 38-54. https://doi.org/10.1016/j.jbankfin.2016.05.009

\section{Published in:}

Journal of Banking \& Finance

\section{Citing this paper}

Please note that where the full-text provided on Manchester Research Explorer is the Author Accepted Manuscript or Proof version this may differ from the final Published version. If citing, it is advised that you check and use the publisher's definitive version.

\section{General rights}

Copyright and moral rights for the publications made accessible in the Research Explorer are retained by the authors and/or other copyright owners and it is a condition of accessing publications that users recognise and abide by the legal requirements associated with these rights.

\section{Takedown policy}

If you believe that this document breaches copyright please refer to the University of Manchester's Takedown Procedures [http://man.ac.uk/04Y6Bo] or contact uml.scholarlycommunications@manchester.ac.uk providing relevant details, so we can investigate your claim.

\section{OPEN ACCESS}




\title{
CEO Inside Debt and Corporate Debt Maturity Structure*
}

\author{
Viet A. Dang and Hieu V. Phan ${ }^{\mathrm{b}}$
}

First version: May 2015

This version: March 2016

\begin{abstract}
This paper examines the relation between chief executive officer (CEO) inside debt holdings and corporate debt maturity. We provide robust evidence that inside debt has a positive effect on short-maturity debt and that this effect is concentrated in financially unconstrained firms that face lower refinancing risk. Our analysis further shows that CEO inside debt helps reduce the cost of debt financing. Overall, our results indicate that managerial holdings of inside debt facilitate access to external debt financing and reduce refinancing risk, thus incentivizing managers to use less costly shorter term debt.
\end{abstract}

JEL classifications: G32, G34.

Keywords: Debt maturity, short-term debt, inside debt, pension, deferred compensation.

\footnotetext{
* We are grateful to two anonymous referees and the editor for their helpful comments and suggestions that have greatly improved the paper. All remaining errors are our own.

${ }^{a}$ Corresponding author. Alliance Manchester Business School, the University of Manchester, Booth Street West, Manchester, M15 6PB, United Kingdom. Email: Vietanh.Dang@manchester.ac.uk (V. A. Dang). Tel.: +44(0) 1612750438 .

${ }^{\mathrm{b}}$ The Robert J. Manning School of Business, University of Massachusetts Lowell, One University Avenue, Lowell, MA 01854, United States. Email:
} 


\section{Introduction}

Recent research shows that a significant part of the executive compensation package comes from pension benefits and deferred compensation (e.g., Bebchuk and Jackson, 2005; Sundaram and Yermack, 2007; Wei and Yermack, 2011; Cassell et al., 2012; Anantharaman et al., 2014; Phan, 2014). These components of executive compensation resemble debt financing because they represent firms' fixed obligations to make future payments to their managers. Hence, pension benefits and deferred compensation can be referred to as "inside debt". Moreover, these components of inside debt are typically unfunded and unsecured. If the firm becomes insolvent, inside debt holders have claims equal to those of other unsecured creditors (Sundaram and Yermack, 2007; Gerakos, 2010; Cassell et al., 2012).

An important feature of chief executive officer (CEO) inside debt is that it can restrain managerial risk-seeking (Edmans and Liu, 2011). Agency theory posits that shareholders, as claimants to the residual value of the firm assets, have an incentive to expropriate creditors' wealth by substituting less risky for more risky investments (Fama and Miller, 1972; Jensen and Meckling, 1976). However, the significant value of inside debt and its order of payment priority in the case of corporate insolvency help align the interests of managers and external creditors, ${ }^{1}$ thus motivating the former to pursue less risky corporate policies. Empirical research provides some evidence in support of this argument. Consistent with the notion that inside debt strengthens manager-debtholder interest alignment, Wei and Yermack (2011) show that the disclosure of large managerial holdings of inside debt leads to value transfer

\footnotetext{
${ }^{1}$ Bebchuk and Jackson (2005) question the effectiveness of inside debt in aligning the interests of managers and external creditors, suggesting that firms and managers can make arrangements to protect the value of inside debt from external creditors, particularly when firms become insolvent. Nevertheless, Gerakos (2010) examines the arrangements for protecting the supplemental executive retirement plans (SERPs), which make up the dominant part of executive pensions, from bankruptcy and shows that only 3 of the 172 firms in his proprietary sample have such arrangements (in the form of secular trusts).
} 
from the shareholders to the creditors and a decrease in the volatility of both equity and debt. Recent studies further find that CEO inside debt holdings are associated with less risky investment and financial policies (Cassell et al., 2012; Phan, 2014), larger cash holdings (Liu et al., 2014), a lower cost of debt and a smaller number of restrictive debt covenants (Anantharaman et al., 2014), and lower payouts (Eisdorfer et al., 2015).

In this paper, we examine the effect of CEO inside debt holdings on an unexplored aspect of debt contracting, namely, the choice of short-term versus long-term debt. We focus on debt maturity structure because it is an important and integrated component of corporate capital structure decisions. It is well established that a firm's debt maturity interacts with its choice of leverage and covenants (e.g., Barclay et al., 2003; Johnson, 2003; Billet et al., 2007). In addition, choice of debt maturity is associated with corporate liquidity policy (Harford et al., 2014) and affects real investment under either favorable or adverse macroeconomic conditions (e.g., Aivazian et al., 2005; Duchin et al., 2010; Almeida et al., 2011). Debt maturity further influences long-term shareholder wealth (Datta et al., 2000) and short-term stock price crash risk (Dang et al., 2016). In sum, it is important to study whether CEO inside debt provides managers with incentives to favor a certain choice of debt maturity, which in turn has relevant implications for other corporate policies and firm value.

There are two competing views about the relation between CEO inside debt holdings and corporate debt maturity. The first view, termed the risk aversion hypothesis, predicts a negative relation between the two variables. This view is based on the notion that managers with inside debt have strong alignment of interests with creditors and hence prefer less risky corporate policies (Jensen and Meckling, 1976; Edmans and Liu, 2011). Since short-term debt requires more frequent renegotiations between the firm and its lenders, it exposes the firm to higher refinancing risk (Diamond, 1991) and subjects its management to greater scrutiny by debt markets (Rajan and Winton, 1995; Stulz, 2000). From a manager's 
perspective, short-maturity debt may be riskier and less preferred than long-term debt. Overall, to the extent that inside debt incentivizes managers to curb their risk-seeking behavior, we expect it to have a negative impact on short-term debt.

In contrast, the alternative hypothesis predicts a positive relation between CEO inside debt and short-maturity debt. This view suggests that managerial holdings of inside debt can mitigate the disadvantages of short-term debt, therefore allowing managers and firms to benefit from this type of debt financing. First, inside debt can help reduce the refinancing risk of short-term debt. As mentioned earlier, firms with CEO inside debt tend to have lower leverage (Cassell et al., 2012) and larger cash reserves (Liu et al., 2014). To the extent that low debt ratios reduce suboptimal liquidation (Johnson, 2003) and large cash holdings alleviate the refinancing problem (Harford et al., 2014), firms that have larger CEO inside debt, and thus adopt more conservative leverage and cash policies, should be less concerned about refinancing risk. Furthermore, inside debt generally improves the debt contracting environment (Anantharaman et al., 2014), thereby enabling firms to refinance more easily. Second, managers with inside debt may be less averse to the monitoring of short-term debt due to their strong alignment of interests with creditors. This is because short-term debt restrains managerial risk-seeking (Barnea et al., 1980; Childs et al., 2005), thus giving managers risk-reducing incentives similar to those provided by inside debt. Put differently, since inside debtholders are likely to already exercise self-monitoring, the additional scrutiny of short-term debt may be a lesser concern for them.

To the extent that CEO inside debt reduces firms' exposure to refinancing risk and mitigates managers' concern about external monitoring, it incentivizes the latter to take on the less costly shorter term debt. Compared to debt with long maturities, short-term debt is typically less costly as it has lower transaction costs (Edwards et al., 2007) and a lower liquidity premium (Bao et al., 2011). In addition, short-term borrowings can effectively 
mitigate both underinvestment and risk-shifting incentives, thus reducing the agency costs of debt (e.g., Myers, 1977; Barnea et al., 1980; Childs et al., 2005). These benefits of short-term debt should improve firms' operating and stock price performance, thus benefiting shareholders and external creditors, as well as inside debtholders, whose payoffs depend on firms' future cash flows. Overall, managers may prefer to use short-term debt to save the cost of financing, reduce investment distortions, improve firm performance, and ultimately increase their payoffs.

To test the two competing hypotheses regarding the relation between CEO inside debt and debt maturity, we first regress the short-term debt ratio, measured as the fraction of debt maturing within three years, on CEO leverage. We define CEO leverage as the ratio of a CEO's inside debt holdings, which are the sum of his/her pension benefits and deferred compensation, to his/her equity value. We do not scale CEO leverage by firm leverage as we wish to alleviate a possible concern that the observed effect of CEO inside debt on short-term debt may be driven by the mechanical relationship between the scaled CEO leverage and firm leverage, the latter an important control in our regressions. However, in our robustness checks, we consider several alternative proxies for CEO inside debt holdings commonly used in the literature (e.g., Wei and Yermack, 2011; Cassell et al., 2012; Phan, 2014).

Using a sample of 1,011 unique firms with 4,793 firm-year observations over the period 2006-2012, we find a significant and positive relation between CEO inside debt and short-term debt. The impact of inside debt on debt maturity is also important economically. Our point estimates indicate that, on average, keeping other variables unchanged at their sample means, a one-standard-deviation increase in CEO leverage is associated with an increase of 1.9 to 8.3 percentage points in the short-term debt ratio. This finding is inconsistent with the risk aversion hypothesis but consistent with the alternative view. 
We subject our baseline results to several robustness tests. We find that they continue to hold when using alternative proxies for CEO inside debt and measures of short-term debt. Our results are also robust to controlling for CEO performance-based incentives proxied by the CEO wealth's sensitivity to stock price and stock return volatility (i.e., CEO delta and CEO vega, respectively). Our results hold when we employ different estimation methods, including the fixed-effects (FE) and first-differences (FD) estimators, which deal with unobserved heterogeneity. Importantly, they persist when we control for the endogeneity of CEO inside debt and a joint determination of debt maturity and firm leverage in (two-stage) generalized method of moments (GMM) regressions. We further show that the impact of CEO inside debt on debt maturity remains significant in a sub-period analysis, in which we consider sub-periods of declining interest rates (2006-2008) or rate stability (2009-2012) and those with an above- or below-median term structure. The impact of CEO inside debt appears to be stronger in the sub-period when interest rates were stable, thus alleviating the concern that our main results are driven by firms' preference for short-term debt when interest rates were declining and refinancing risk was low.

According to our alternative hypothesis, the mechanism driving the positive relation between CEO leverage and short-maturity debt is that CEO inside debt helps align the interests of managers and creditors, thus facilitating firms' access to external debt financing and alleviating the refinancing risk of short-term debt. This favorable debt contracting setting motivates firms to use the typically riskier but less costly shorter term debt. To provide further support for this mechanism, we examine subgroups of firms according to their degree of financial constraint. Since unconstrained firms with managerial holdings of inside debt tend to hoard more cash (Liu et al., 2014) and as a result have lower refinancing risk (Harford et al., 2014), we expect the effect of CEO leverage on short-term debt to be stronger for these firms. This analysis also helps to alleviate a potential concern that the use of short-term debt 
does not reflect a firm's debt maturity choice but is imposed by lenders, especially if the firm is constrained and has limited access to long-term borrowings. In contrast, the choice of short-term debt among unconstrained firms is likely a result of their own decision making. Our results reveal that the positive relation between CEO leverage and short-term debt is present only among unconstrained firms, which have more liquidity and lower refinancing risk. This finding is in line with our alternative hypothesis.

While using the balance sheet data allows us to examine the effect of CEO inside debt on debt maturity on both a cross-sectional and a time-series basis, this approach has a few potential drawbacks. Since firms do not recapitalize frequently (Leary and Roberts, 2005; Strebulaev, 2007), their capital structure and debt maturity may be the result of their past decisions. Our measure of short-term debt as the fraction of debt due within three years can be affected by the current proportion of long-term debt that is maturing. On the other hand, the value of inside debt typically increases with CEO age (Sundaram and Yermack, 2007). Hence, our documented positive relation between CEO inside debt holdings and short-term debt, based on balance sheet data, may be spurious.

To address the potential problems with the balance sheet data mentioned above, we investigate the relation between CEO inside debt and debt maturity when firms raise debt using new debt issue data. This approach also allows us to better capture the role of managerial holdings of inside debt in determining the terms of new debt contracts, especially from a creditor's perspective. Our analysis of the new debt issue data reveals a negative impact of CEO inside debt on the maturities of new debt issues, which is consistent with our finding using the balance sheet data, and provides further support for the alternative view.

Using the new debt issue data also enables us to investigate the relation between CEO inside debt and yield spreads. If CEO inside debt is truly debt-like and effective at curbing managerial risk-seeking, it should lead to a lower cost of debt (Anantharaman et al., 2014). 
The results from our analysis indicate a negative relation between CEO inside debt and yield spreads, supporting this argument. Further results regarding the interaction term between CEO leverage and bond maturity suggest that firms with inside debt benefit most from the decrease in yield spreads by taking on more short-term debt. This analysis thus enables us to demonstrate that firms with CEO inside debt can take advantage of the resulting lower refinancing risk and lower yield spreads by shortening their debt maturity and making further cost savings, which is in line with the alternative hypothesis. In addition, together with the results conditional on financial constraints, this analysis rules out the possibility that the positive effect of CEO inside debt on short-maturity debt is driven by confounding factors. If the shortening of debt maturity were to reflect a firm's limited access to long-term debt or external creditors' concerns about its risk profile, the relation between CEO inside debt and the cost of debt would be positive, in contrast to our findings.

Our research adds to the literature in four ways. First, to the best of our knowledge, this is the first study that examines the relation between CEO inside debt and debt maturity structure. Our paper therefore contributes to an established and ever growing body of literature documenting various determinants of corporate debt maturity (e.g., Barclay and Smith, 1995; Guedes and Opler, 1996; Johnson, 2003; Billet et al., 2007; Zheng et al., 2012), as well as factors explaining the secular increase in the use of short-maturity debt (Custodio et al., 2013; Harford et al., 2014). We provide novel evidence that executive compensation in the form of inside debt plays an important role in shaping firms' debt maturity policies.

Second, our study extends prior research investigating the relation between executive compensation and debt maturity, which has largely focused on equity-based compensation. ${ }^{2}$

\footnotetext{
${ }^{2}$ The lack of research on CEO inside debt and debt maturity may be due to data unavailability prior to 2006. Since the introduction of the disclosure requirement by the Securities and Exchange Commission (SEC) on December 15, 2006, firms have had to report the value of executive pensions and deferred compensation, the two components of inside debt, in all proxy statements filed.
} 
Datta et al. (2005) find that when managers have strong interest alignment with shareholders, they have an incentive to shorten debt maturity and subject themselves to the monitoring of short-term debt. Brockman et al. (2010) show that CEO portfolio deltas (vegas) have a positive (negative) effect on debt maturity, which is consistent with creditors understanding the risk incentives induced by option-based compensation and hence adjusting the debt maturity to mitigate those incentives. Our research adds to these studies by providing evidence of a significant and negative relation between CEO inside debt and debt maturity structure. This relation continues to hold when we control for the effect of equity-based compensation.

Third, our paper adds to the literature that documents significant effects of CEO inside debt on various corporate financial policies, as reviewed above. Specifically, our study complements recent evidence of the impacts of CEO inside debt on related but different aspects of debt contracting, including leverage (Cassell et al., 2012), bond prices and volatility (Wei and Yermack, 2011), and debt covenants and the cost of debt financing (Anantharaman et al., 2014). Our findings indicate that CEO inside debt not only leads to a lower cost of debt, which is consistent with Anantharaman et al.'s (2014) recent evidence, but also results in shorter maturity debt financing.

Finally, our research contributes to a broader debate that has important implications for firms in terms of determining the optimal structure of executive compensation that not only aligns the interests of managers and shareholders, ${ }^{3}$ but also alleviates shareholderbondholder conflicts and reduces the agency costs of debt (e.g., John and John, 1993).

The rest of our paper proceeds as follows. Section 2 develops the hypotheses. Section 3 describes the sample and main variable construction. Section 4 presents our empirical models and discusses the regression results. Section 5 concludes.

\footnotetext{
${ }^{3}$ See Smith and Stulz (1985), Guay (1999), Knopf et al. (2002), and Coles et al. (2006) for broader literature showing how executive compensation, in the form of stocks and stock options, affects corporate policies.
} 


\section{Hypotheses}

We develop two competing views regarding the potential effects of CEO inside debt holdings on debt maturity structure: the risk aversion and the alternative hypotheses. ${ }^{4}$

\section{Risk aversion hypothesis}

Theoretically, managers with inside debt have the same exposure to default risk as external creditors. Thus, they have an incentive to mitigate agency problems arising from stockholder-bondholder conflicts and curb their own risk-seeking behavior (Jensen and Meckling, 1976; Edmans and Liu, 2011). Existing studies provide some evidence in support of this argument. Cassell et al. (2012), for example, show that CEO inside debt holdings help reduce firm risk and lead to more conservative investment and financial policies. Using the same line of argument, we contend that managers with inside debt prefer long-term debt to short-term debt because debt with longer maturities exposes firms to lower refinancing risk and provides them with more stability. Short-term debt, on the other hand, requires more frequent debt renegotiations between the borrowing firm and its creditors, thus exposing the firm to higher refinancing risk and subjecting its managers to greater scrutiny by debt markets (e.g., Calomiris and Kahn, 1991; Diamond, 1991; Leland and Toft, 1996; Rajan and Winton, 1995; Stulz, 2000). Additionally, while managers with strong interest alignment with shareholders self-impose the external monitoring of short-term debt (Datta et al., 2005), those with inside debt and consequently weak incentive alignment with shareholders may prefer less monitoring and scrutiny, possibly for entrenchment purposes. Taken together, these arguments imply that inside debt holdings incentivize managers to use longer-maturity debt. We thus formulate our first hypothesis as follows:

Hypothesis 1a: CEO inside debt is negatively related to short-term debt.

\footnotetext{
${ }^{4} \mathrm{We}$ are grateful to the reviewers for encouraging us to elaborate on these competing hypotheses.
} 


\section{Alternative hypothesis}

CEO inside debt enables managers to overcome certain drawbacks of short-maturity debt while motivating them to take advantage of this type of debt financing. As mentioned, the main disadvantage of using short-term debt is that it exposes the firm to refinancing risk. We argue, however, that CEO inside debt can help reduce this risk. Our argument is based on existing evidence that $\mathrm{CEO}$ inside debt motivates firms to adopt conservative financial policies, which have implications for refinancing risk. Specifically, firms with larger inside debt have lower financial leverage (Cassell et al., 2012), larger cash reserves (Liu et al., 2014), and lower payouts (Eisdorfer et al., 2015). To the extent that low debt ratios reduce bankruptcy and suboptimal liquidation concerns (Johnson, 2003) and large cash balances alleviate the refinancing problem associated with short-term debt (Harford et al., 2014), firms that have larger CEO inside debt, and consequently adopt more conservative policies, should be less concerned about refinancing risk. Moreover, CEO inside debt generally improves access to external debt financing, resulting in fewer restrictive covenants and a lower cost of debt (Anantharaman et al., 2014). This favorable debt contracting setting enables firms with larger inside debt to refinance more easily.

From the managers' perspective, another potential drawback of using short-term debt is the increased monitoring by external creditors. ${ }^{5}$ As argued above, managers with weak alignment of interests with shareholders may have an incentive to avoid the frequent and stringent monitoring of short-term debt. While this argument reflects the preference of selfinterested managers for less monitoring, it may be less applicable to managers who share interests and objectives with debtholders. We contend that managers with larger inside debt holdings become less averse to the external monitoring by creditors because they have stronger incentive alignment with them. Specifically, both managers with inside debt and

\footnotetext{
${ }^{5}$ We thank a reviewer for the suggestion to address the monitoring role of short-term debt.
} 
external creditors are exposed to default risk and thus have a lower risk appetite. To the extent that short-term debt financing reduces managerial discretion and risk-seeking behavior (Barnea et al., 1980; Childs et al., 2005), it creates risk-reducing incentives similar to those provided by inside debt. Put simply, managers with inside debt may already subject themselves to self-monitoring and discipline, such that any additional scrutiny by creditors may be a lesser concern for them.

Since CEO inside debt helps reduce the potential drawbacks of short-term debt, it incentivizes managers to take on this beneficial form of financing. The most significant benefit of short-maturity debt is that it is generally less costly than long-maturity debt. Debt with shorter maturities has a lower cost of financing as it involves lower transaction costs (Edwards et al., 2007) and a lower liquidity premium (Bao et al., 2011). Short-term debt is also less sensitive to information and thus has a lower adverse-selection discount (e.g., Gorton and Pennacchi, 1990). In addition, short-term debt helps reduce both underinvestment and risk-shifting incentives, thus lowering the agency costs of debt financing (Myers, 1977; Barnea et al., 1980; Leland and Toft, 1996). Childs et al. (2005) show that firms with financial flexibility and low refinancing risk optimally choose short-term debt, which can mitigate, if not completely eliminate, investment distortions. The important benefits of shortterm debt in effectively reducing the agency costs of debt and enhancing firm value are likely to be above and beyond the benefit of CEO inside debt holdings in curbing managerial riskseeking behavior.

The above benefits of short-term debt should help improve firms' operating and stock price performance, thus benefiting not only their shareholders but also their debtholders, including inside debtholders, whose payoffs are tied to the cash reserves and future cash flows generated by the firm. Moreover, a CEO's pension benefits are typically calculated based on the CEO's average salary and bonus earned over the last three years or in the 
highest consecutive three-year period during his/her employment (Sundaram and Yermack, 2007); the salary and bonus, in turn, depend on the firm's performance. These arguments suggest that managers with inside debt holdings stand to gain from the benefits of short-term debt.

The discussion above demonstrates that a manager with inside debt should choose an appropriate debt maturity structure by weighing the costs and benefits of using short-term debt. To the extent that CEO inside debt reduces firms' exposure to refinancing risk and lowers the cost of debt financing, it incentivizes managers to take on the lower cost, shorter term debt; this choice of debt maturity, in turn, may help reduce investment distortions, improve firm performance, and ultimately increase managers' payoffs. These arguments lead to the following alternative hypothesis:

Hypothesis 1b: CEO inside debt is positively related to short-term debt.

\section{Sample, Variable Construction, and Descriptive Statistics}

To test our competing hypotheses, we use two samples, a debt maturity sample based on the balance sheet data and a new debt issue sample from Thomson Reuters' SDC Platinum Global New Issues that span 2006-2012. We collect CEO compensation and ownership data from Standard \& Poor's ExecuComp database. Financial and stock return data are from Compustat annual files and CRSP monthly files, respectively. Finally, we collect yields on long-term government bonds and Treasury bills from the St. Louis Federal Reserve Bank website. $^{6}$

The main test variable in our analysis is CEO leverage, which is measured as the ratio of a CEO's inside debt holdings, including pension benefits and deferred compensation, to his/her equity value. To ensure the robustness of our results, we also use alternative proxies

\footnotetext{
${ }^{6}$ Available at: https://research.stlouisfed.org/fred2/release?rid=18, last accessed on July 1, 2015.
} 
for CEO inside debt holdings, including (1) relative CEO leverage $(k)$, which is measured as the CEO's debt-to-equity ratio divided by the firm's debt-to-equity ratio, (2) relative CEO leverage $>1$ dummy ( $k$ dummy), which takes a value of 1 if the relative CEO leverage is greater than 1 and 0 otherwise, (3) relative CEO incentive $\left(k^{*}\right)$, which is the ratio of the marginal change in the value of the CEO's inside debt holdings to the marginal change in the value of the CEO's inside equity holdings, divided by the ratio of the marginal change in the firm's debt to the marginal change in the firm's equity, given a change in the firm's value, and (4) relative CEO incentive > 1 dummy ( $k^{*}$ dummy), which takes a value of 1 if the relative CEO incentive is greater than 1 and 0 otherwise. Appendix 1 provides a detailed summary of how we calculate alternative measures of CEO inside debt holdings. Following prior research (e.g., Cassell et al., 2012; Anantharaman et al., 2014; Phan, 2014), we include only those firm-year observations that have positive CEO inside debt values in our sample.

In terms of our dependent variable, we measure short-term debt as the fraction of debt due within three years (Barclay and Smith, 1995; Johnson, 2003; Billett et al., 2007; Brockman et al., 2010; Harford et al., 2014). To address the concern that this measure is based on an arbitrary cutoff point, in our robustness checks, we consider alternative measures by using the proportions of debt maturing within one, two, and five years. Following previous studies of debt maturity structures (e.g., Johnson, 2003; Datta et al., 2005; Brockman et al., 2010; Custodio et al., 2013; Harford et al., 2014), we control for the following variables in our regressions of short-maturity debt on CEO inside debt holdings: firm size, firm size squared, market-to-book, abnormal earnings, asset maturity structure, asset volatility, firm leverage, research and development $(R \& D)$ expenses and its dummy variable, and the term structure of interest rates. We provide detailed definitions of the variables in Table A.1 of Appendix 2. 
Table 1 reports the summary statistics for the variables in our regressions. We winsorize all variables at the 1st and 99th percentiles to alleviate the impact of extreme values. The main measure of short-term debt, which is the fraction of short-term debt maturing within three years (ST3), has a mean value of $35.8 \%$, which is slightly lower than the mean values of $39.8 \%$ and $40 \%$ reported previously in Datta et al. (2005) and Brockman et al. (2010), respectively. The summary statistics for the alternative measures of debt maturity, namely, short-term debt due in one, two, and five years, are in line with those reported in previous research.

[Insert Table 1 about here]

The summary statistics for our test variable, CEO leverage, are consistent with those reported in recent studies of CEO inside debt. Specifically, on average, CEO inside debt holdings are about one half of CEO equity holdings. In addition, CEO leverage is more than double firm leverage. The average chief financial officer (CFO) also holds a significant part of his/her compensation in inside debt. These statistics confirm the previous finding in the literature that inside debt is an important part of managerial compensation.

\section{Empirical Models, Regression Results, and Discussion}

\subsection{Debt Maturities from Balance Sheet Data}

\subsubsection{Baseline Regressions}

We start our analysis by examining the relation between CEO leverage and short-term debt reported on firms' balance sheets, while controlling for other factors that have the power to explain debt maturity. We estimate the following model:

$$
S T 3_{i t}=\alpha_{0}+\alpha_{1} C E O_{-} \text {leverage } e_{i t}+\boldsymbol{\theta}^{\prime} \boldsymbol{X}_{i t}+\varepsilon_{i t},
$$

where the dependent variable, $S T 3$, is the short-term debt ratio. $\boldsymbol{X}_{i t}$ is a vector of the controls, including firm size, firm size squared, market-to-book, abnormal earnings, asset maturity 
structure, asset volatility, firm leverage, $R \& D$ expenses and its dummy variable, and the term structure of interest rates. ${ }^{7}$

Firm size is often used as a proxy for asymmetric information (Scherr and Hulburt, 2001) and credit quality (e.g., Johnson, 2003). Since large firms tend to have better credit quality and less information asymmetry, we expect firm size and short-maturity debt to be negatively related. We further use firm size squared to capture the potentially non-monotonic relationship between credit quality and short-term debt (Diamond, 1991). Next, we expect a positive relation between market-to-book and short-maturity debt since firms with high growth opportunities should use more short-term debt to alleviate underinvestment incentives (Myers, 1977). Abnormal earnings and short-term debt should be positively related because firms with larger abnormal earnings will be more likely to use short-maturity debt as a signaling device (Flannery, 1986). Myers' (1977) underinvestment hypothesis predicts that firms will match the maturity structures of their assets and liabilities, which implies a negative relation between asset maturity and short-term debt. Firms with high earnings volatility prefer using long-term debt to reduce the refinancing and liquidity risks associated with short-maturity debt, thus implying a negative association between volatility and shortterm debt (Kane et al., 1985). Similarly, we expect firm leverage and short-maturity debt to be negatively related since highly leveraged firms prefer debt with a longer maturity to mitigate the refinancing and liquidity risks (Johnson, 2003). Firms with more $R \& D$ expenses face greater asymmetric information problems and thus tend to hold more short-term debt (Custodio et al., 2013). To overcome the problem of the unavailability of data for R\&D expenses, we include a dummy variable ( $R \& D$ dummy) that is equal to 1 if the $R \& D$ expenses are missing and 0 otherwise (Flannery and Rangan, 2006). Brick and Ravid (1991) argue that,

\footnotetext{
${ }^{7}$ As in previous research (e.g., Brockman et al., 2010), we use contemporaneous values of the variables in the debt maturity equation. However, we obtain qualitatively similar results when regressing short-term debt on lagged CEO leverage and either the contemporaneous or lagged values of the control variables.
} 
if the term structure of interest rates is upward sloping, firms should lengthen their debt maturity structures to exploit the greater tax advantages of long-term debt; thus, we expect term structure and short-term debt to be negatively related.

Table 2 reports the results of our baseline regressions. In column 1, we regress shortterm debt on the control variables. Consistent with our expectations, we find that short-term debt is negatively related to firm size but positively associated with firm size squared. The effects of asset maturity structure and firm leverage on short-maturity debt are significantly negative. These results are generally in line with prior theoretical predictions and empirical evidence in the literature (e.g., Johnson, 2003; Brockman et al., 2010). On the other hand, the coefficients on market-to-book and $R \& D$ expenses are positive but insignificant, while those on abnormal earnings and the term structure of interest rates are significant with unexpected signs. Overall, the coefficient estimates of the control variables are broadly consistent with previous evidence in the literature (e.g., Brockman et al., 2010).

[Insert Table 2 about here]

In column 2, we regress short-maturity debt on our test variable, CEO leverage, and the controls. We find that CEO leverage is positive and significant at the $1 \%$ level, which provides support for our alternative hypothesis (Hypothesis 1b) that managers with inside debt are more likely to use short-maturity debt. This finding is, however, inconsistent with the risk aversion hypothesis (Hypothesis 1a). We note that the coefficients on the control variables are qualitatively similar to those in column 1 , suggesting that the impact of CEO leverage on debt maturity is not driven by its correlation with other firm characteristics. For the purpose of illustration, we use the point estimates in column 2 to calculate the economic effect of CEO leverage on short-maturity debt. Keeping other variables unchanged at their sample means, we find that a one-standard-deviation increase in CEO leverage leads to a 1.9 
percentage point increase in the fraction of debt maturing within three years, which represents a $5.5 \%(7.0 \%)$ increase relative to the mean (median) of the short-maturity debt variable.

In column 3, we estimate the baseline model in first differences (i.e., a change regression). This estimation enables us to address a few potential problems with our baseline regression. First, since CEO inside debt holdings tend to increase with CEO age, while debt maturity follows a secular decrease (Custodio et al., 2013), the observed positive relation between CEO leverage and short-term debt could be due to a spurious relationship between them. Furthermore, because our measure of short-maturity debt includes the proportion of long-term debt that is maturing, it may reflect past debt maturity decisions made by former rather than current managers. By estimating the change regression, we can better capture how a marginal change in a firm's CEO leverage leads to a marginal change in its debt maturity, thus addressing the potential issues mentioned above. Another advantage of this regression is that it uses the first-difference transformation, which helps alleviate the endogeneity concern due to the presence of (time-invariant) omitted variables (Brockman et al., 2010).

In columns 4-9, we estimate alternative model specifications to establish the strength of the baseline results. First, in column 4, we control for the recently documented secular decrease in debt maturity (Custodio et al., 2013) by adding year dummies. In column 5, we control for industry characteristics that may affect debt maturity choices at the firm level by including two-digit Standard Industrial Classification (SIC) industry dummies. In column 6, we control for both year and industry dummies to account for time effects and industry effects on the variation of short-term debt. In column 7, we use the Tobit model to address a concern that the short-maturity debt variable is, by definition, censored at 0 and 1 (Zheng et al., 2012). In estimating this Tobit model, we further employ the firm fixed effects estimator to account for unobserved firm characteristics that may affect debt maturity structures (e.g., Johnson, 2003; Datta et al., 2005). We also use the fixed effects method to re-estimate the 
(linear) baseline model in column 8. Finally, in column 9, we control for both firm fixed effects and year fixed effects. Across all alternative model specifications, we find that the results are qualitatively similar to those obtained in column 2 . In particular, the coefficient estimates of the test variable, CEO leverage, are all significant and positive, ranging from 0.012 to 0.017 . This evidence suggests a statistically and economically significant relationship between CEO leverage and the firm's debt maturity structure, which is in line with Hypothesis $1 b$.

\subsubsection{Robustness Checks}

We perform several tests to establish the robustness of our baseline results. First, we show that our results are insensitive to alternative measures of CEO inside debt holdings. Anantharaman et al. (2014) find that the effects of CEO inside debt on the terms of debt contracts mostly arise from the pension component of inside debt, whereas the other component, deferred compensation, has little effect. Based on this finding, we decompose CEO inside debt holdings into pensions and deferred compensation and regress shortmaturity debt on each component. The results in columns 1 and 2 of Table 3 show that $C E O$ pensions are positively related to short-term debt but CEO deferred compensation has little effect on short-term debt. In column 3 , we further regress short-maturity debt on both CEO pensions and deferred compensation. Again, we find that the coefficient on the former variable is significantly positive, while the coefficient on the latter is insignificant. Taken together, these findings are consistent with the evidence documented by Anantharaman et al. (2014) that the average incentive-alignment effect of debt-like compensation is driven by executive pensions.

\section{[Insert Table 3 about here]}

In columns 4-7 of Table 3, we further demonstrate the strength of our baseline results using other measures of CEO inside debt holdings, namely, relative CEO leverage $(k)$, 
relative CEO incentive ( $\left.k^{*}\right)$, a relative CEO leverage dummy ( $k$ dummy), and a relative CEO incentive dummy ( $k^{*}$ dummy). The results show that all these alternative proxies for CEO inside debt holdings are positively associated with the short-term debt ratio. The coefficients on those measures are also economically significant. Specifically, keeping other variables unchanged at their sample means, a one-standard-deviation increase in either relative CEO leverage $(k)$ or relative CEO incentive $\left(k^{*}\right)$ leads to an increase of approximately 3.7 percentage points in the short-term debt ratio, or a $10.6 \%(13.6 \%)$ increase relative to the mean (median). Overall, the results in Table 3 indicate that our main findings are insensitive to alternative proxies for CEO debt-like compensation.

Second, we follow the debt maturity literature and show that our results also hold for alternative measures of our dependent variable, the short-term debt ratio (Harford et al., 2014). In columns 1-3 of Table 4, we measure short-term debt as the proportion of total debt maturing within one (ST1), two (ST2), and five years (ST5), respectively. Based on Huang et al. (2016), we also calculate a new measure of short-term debt, debt maturing within one year, net of the current proportion of long-term debt (STNP). This new measure is, by construction, not affected by maturing long-term debt. We find that, except when shortmaturity debt is defined as debt maturing within five years, the coefficients on CEO leverage remain positive and statistically significant at the $1 \%$ level. We thus conclude that our main findings are generally robust to alternative proxies for measuring short-term debt.

[Insert Table 4 about here]

As a third robustness check, we demonstrate that our results continue to hold after controlling for CEO performance-based compensation, CEO stock ownership, and CFO inside debt holdings. As mentioned, Brockman et al. (2010) find debt maturity to be related to two measures of CEO performance-based compensation, CEO delta and CEO vega. To control for the impacts of these performance-based incentives on short-term debt, we include 
them in our baseline regression. Next, Datta et al. (2005) find that managers whose incentives are more aligned with those of shareholders prefer to use short-maturity debt. Thus, we also control for CEO stock ownership, a measure of the degree of manager-shareholder interest alignment. Finally, Chava and Purnanandam (2010) argue that debt maturity choices are more closely associated with CFOs' incentives than with those of CEOs. To address this possibility, we construct a $C F O$ leverage variable and include it in our baseline regression.

[Insert Table 5 about here]

The results in column 1 of Table 5 show that short-maturity debt is negatively (positively) related to CEO delta (CEO vega), which is consistent with Brockman et al. (2010). In column 2, we find that CEO stock ownership is positive and marginally significant at the $10 \%$ level, which is in line with Datta et al. (2005). The results in column 3 show that debt maturity choices are affected by CFOs' risk preferences, supporting Chava and Purnanandam (2010). Importantly, across all models, we find that the coefficient on our variable of interest, $C E O$ leverage, remains positive and statistically significant, again in line with the baseline results and Hypothesis $1 b$.

\subsubsection{Dealing with Endogeneity}

Corporate debt maturity and leverage can be jointly determined, thereby giving rise to a potential simultaneity problem (e.g., Barclay et al., 2003; Johnson, 2003; Billett et al., 2007). Failing to control for endogeneity due to a possible simultaneous relationship between debt maturity and leverage may render our coefficient estimates biased and inconsistent. Thus, we address this endogeneity concern by running a two-stage regression using the GMM estimator (Brockman et al., 2010). ${ }^{8}$ Similar to Johnson (2003), Datta et al. (2005), and

\footnotetext{
${ }^{8}$ The two-stage GMM estimator provides efficient estimates of the coefficients and consistent estimates of the standard errors; it is more efficient than the traditional (instrumental variable/two-stage least squares) IV/2SLS estimator (see also Baum et al., 2003).
} 
Brockman et al. (2010), we use asset tangibility (proxied by property, plant, and equipment (PPE)) as an instrument for leverage. While prior research finds tangibility to be one of the most important determinants of firm leverage (Frank and Goyal, 2009), it does not establish any theoretical link between tangibility and debt maturity structure. This suggests that tangibility satisfies both the relevance and exclusion conditions of a valid instrument.

Column 1 of Table 6 reports the first- and second-stage regression results of our GMM estimation. Specifically, in the first stage, we regress firm leverage on its instrument, tangibility, and other exogenous variables. In the second stage, we perform a regression of debt maturity on the predicted values of firm leverage using the first-stage estimates, our test variable, CEO leverage, and other control variables. The results of the first-stage regression suggest that tangibility has a positive effect on firm leverage, which is consistent with our expectation. Our diagnostic tests also confirm the validity of our instrument and specification. Importantly, the second-stage results show that CEO leverage continues to have a positive effect on short-maturity debt, which is consistent with our baseline regression results. ${ }^{9}$

[Insert Table 6 about here]

The second potential concern about our baseline regression is that CEO inside debt holdings and debt maturity structure can be jointly determined or correlated with unobserved firm characteristics, such as the firm's financial condition. To alleviate this endogeneity concern, we perform a two-stage regression using the GMM estimator. Following previous research, we use the natural logarithm of CEO age and the annual industry-median CEO leverage as two instruments for CEO leverage (Sundaram and Yermack, 2007; Cassell et al.,

\footnotetext{
${ }^{9}$ In further (untabulated) analysis we follow previous research (Johnson 2003; Brockman et al. 2010) and estimate a system of two simultaneous equations of debt maturity and leverage. Our main findings regarding the impact of CEO inside debt on short-maturity debt are qualitatively unchanged.
} 
2012; Anantharaman et al., 2014). ${ }^{10}$ The first-stage results, reported in column 2 of Table 6, show that our instruments, CEO age (in natural logarithm) and the industry-median CEO leverage, are both statistically significant as expected. Further diagnostic tests, including the $F$-test for the joint significance of the instruments, confirm the validity of these instruments. More importantly, the second-stage results show that the relation between CEO leverage and short-term debt remains positive and statistically significant after controlling for the endogeneity of CEO inside debt holdings.

Finally, we address the concern that both firm and CEO leverage are endogenously related to corporate debt maturity. Since our previous results show that tangibility and CEO age (in natural logarithm) are valid instruments for firm and CEO leverage, respectively, we use these two instruments in our GMM estimation that treats both firm and CEO leverage as endogenous. In column 3 of Table 6, the two-stage GMM regression results confirm that the instruments are valid and that the positive effect of CEO leverage on short-maturity debt remains statistically and economically significant. Indeed, the coefficient estimate on CEO leverage has a greater magnitude, 0.083 , than the baseline regression result of 0.018 . This new finding indicates that, controlling for endogeneity concerns, a one-standard-deviation increase in CEO leverage leads to an increase of 8.3 percentage points in the short-term debt ratio, which is equivalent to a $23 \%$ (30\%) increase relative to its mean (median). This evidence again suggests that CEO leverage is an economically important determinant of debt maturity choice.

\footnotetext{
${ }^{10}$ In untabulated analysis, we also experiment using other known instruments of CEO leverage, including a new CEO dummy variable, liquidity constraints, tax status, and the maximum tax rate on individual income. We find that these instruments are not significant in the first stage of the regression, and further diagnostic test statistics prove to be unsatisfactory.
} 


\subsubsection{CEO Inside Debt and Short-term Debt: Sub-period Analysis ${ }^{11}$}

Our sample period 2006-2012 includes sub-periods with different market conditions and interest rate patterns. Our examination of the term structure of interest rates (untabulated) shows that both the short-term (1-year) and longer term (10-year) Treasury rates exhibited a steep decline from the beginning of 2006 to the end of 2008 before leveling off from 2009 to 2012. These patterns correspond to two eras, one of declining rates and one of rate stability. To the extent that firms have incentives to use short-term debt at a time of rapidly declining rates, possibly due to lower refinancing risk, our evidence for the whole sample may be driven by the results for this period. Hence, to examine the robustness of our results, we split the sample period into 2006-2008 and 2009-2012 and rerun our baseline regression for each sub-period.

In column 1 of Table 7, the second-stage GMM regression results show that the coefficients on CEO leverage are positive for both sub-periods. ${ }^{12}$ They are significant at the $10 \%$ level for the sub-period 2006-2008 and significant at the $1 \%$ level for the sub-period 2009-2012. This finding indicates that the positive effect of CEO leverage on short-maturity debt persists throughout our sample period and, importantly, holds true in the sub-period of rate stability. The weaker evidence for 2006-2008 may be driven by the fact that while both short- and long-term rates were declining, the difference between them was relatively small, reducing the incentive for firms to use short-term debt. ${ }^{13}$

\section{[Insert Table 7 about here]}

As a related robustness check, we examine sub-periods with an above- and belowmedian term structure of interest rates. This test is motivated by an observation that the

\footnotetext{
${ }^{11}$ We thank a reviewer for encouraging us to pursue this line of inquiry.

${ }^{12}$ To conserve space, we do not report the first-stage regression results.

${ }^{13}$ Our results (untabulated) are robust to using different time windows, such as 2006-2007 and 2008-2012 or 2006-2009 and 2010-2012.
} 
difference between the 10-year and 1-year government bond yields was relatively small in more than half our sample period. If a small yield spread reduces the incentive for firms to favor short-term debt over long-term debt, it may weaken the relation between CEO leverage and short-maturity debt for the whole sample period. In column 2 of Table 7, we find that the effect of CEO leverage on short-maturity debt is positive and statistically significant for both sub-periods with an above- and below-median term structure. However, the coefficients on CEO leverage are not significantly different between the sub-periods. A potential explanation for this finding is that the period in which the term structure was narrow also coincided with the era of declining rates, which may give firms an incentive to use short-term debt. Overall, our results suggest that the positive relation between CEO leverage and short-maturity debt persists throughout our sample period.

\subsubsection{CEO Inside Debt, Short-term Debt, and Financial Constraints}

Our analysis has thus far provided robust evidence in support of Hypothesis $1 b$. According to this view, the mechanism driving the positive relation between CEO inside debt and debt maturity is that the former facilitates firms' access to external debt financing and lowers the refinancing risk associated with short-term debt; this in turn creates a favorable debt contracting environment for the firm and motivates its managers to choose the less costly shorter term debt. To provide additional evidence for this mechanism, we investigate the relation between CEO leverage and debt maturity for subgroups of firms based on their degree of financial constraint. Since unconstrained firms with larger CEO inside debt tend to hoard more cash (e.g., Liu et al., 2014) and as a result have lower refinancing risk (Harford et al., 2014), we expect a more pronounced positive effect of CEO leverage on short-term debt for these firms. This additional analysis also allows us to alleviate a potential concern that the use of short-term debt does not reflect a firm's debt maturity choice but rather the consequence of its limited access to long-term debt financing. In particular, constrained firms 
may use short-term debt because they are likely to be screened out of the long end of the maturity spectrum (Diamond, 1991). In contrast, the use of short-term debt in unconstrained firms should reflect their debt maturity choice.

To measure the degree of financial constraint, we employ four proxies commonly used in the literature: the size and age (Hadlock and Pierce, 2010) index, the Whited and Wu (2006) index, dividend paying status (Fazzari et al., 1998), and credit rating status (Faulkender and Petersen, 2006). We categorize firms into the constrained group if they have an above-median size-age index, an above-median Whited-Wu index, zero dividend, or no credit rating. We define firms as unconstrained if they have a below-median size-age index, a below-median Whited-Wu index, non-zero dividends, or a credit rating.

In Table 8, we present the second-stage regression results obtained using the GMM estimator. Columns 1-4 show a positive and significant relation between CEO leverage and short-maturity debt for the unconstrained group, and an insignificant relation for the constrained group. ${ }^{14}$ The finding that inside debt motivates managers to select short-term debt among unconstrained firms, which have more liquidity and lower refinancing risk, is in line with Hypothesis $1 b$.

[Insert Table 8 about here]

\footnotetext{
${ }^{14}$ We also address the concern that the relation between CEO inside debt holdings and debt maturity structure is confounded by the effects of inside debt on cash holdings (Liu et al., 2014) and the degree of financial constraint. For example, since firms with more inside debt may hold more cash (Liu et al., 2014), the positive effect of CEO inside debt on short-term debt may simply reflect the positive relation between cash and shortterm debt (Harford et al., 2014). Hence, we include cash holdings and alternative measures of financial constraint in the regressions. Our main results are qualitatively unchanged after controlling for those variables.
} 


\subsection{Maturities of New Debt Issues}

\subsubsection{Maturities of New Debt Issues}

While using the balance sheet data enables us to examine the relation between CEO inside debt and debt maturity on both a cross-sectional and a time-series basis, it has a few potential drawbacks. Specifically, our evidence thus far of a positive impact of CEO leverage on short-term debt may be spurious. The reason is that, because firms do not adjust their capital structure frequently (Leary and Roberts, 2005; Strebulaev, 2007), both financial leverage and the debt maturity structure may be the result of their past decisions, whereas the value of CEO debt-like compensation typically increases with CEO age (Sundaram and Yermack, 2007). In particular, our measure of short-maturity debt as debt due within three years may be affected by long-term debt that is maturing.

Guedes and Opler (1996) argue that an incremental approach focusing on new debt issues is more useful in studying the determinants of debt maturity at all points of the maturity spectrum. Importantly, this method completely avoids the potential problem in the measurement of short-maturity debt due to maturing long-term debt. It further allows us to take the perspective of a creditor, who determines the terms of new debt contracts upon evaluating the impact of managerial holdings of inside debt. Based on these arguments and following recent studies (e.g., Brockman et al., 2010; Custodio et al., 2013), we next examine the relation between CEO inside debt and the maturity of new debt issues.

Our data on new debt issues from the SDC database consist of 367 straight debt issues from 159 unique firms in $2006-2012 .{ }^{15}$ We construct a new dependent variable using the

\footnotetext{
${ }^{15}$ Since the data on CEO inside debt holdings have only been available recently, our sample period 2006-2012 is relatively short while our sample of new debt issues is relatively small. Hence, we prefer to use the incremental approach in sensitivity checks, rather than in our main regressions in Section 4.1. Further research may consider this approach in the main test when the data become more available.
} 
natural logarithm of the maturity of new debt issues, $\operatorname{Ln}($ Bond_Mat). In our regressions, the test variable, CEO leverage, and the control variables are similar to those in Section 4.1; we include their lagged values following prior research (Brockman et al., 2010). Our model takes the following form:

$$
\operatorname{Ln}(\text { Bond_Mat })_{i t}=\beta_{0}+\beta_{1} C E O_{-} L \text { everage } e_{i, t-1}+\boldsymbol{\theta}^{\prime} \boldsymbol{X}_{i, t-1}+\varepsilon_{i t} \text {. }
$$

The results in column 1, Table 9, show that the coefficient on CEO leverage is significantly negative, suggesting that firms with larger CEO inside debt holdings issue debt with shorter maturities. This finding does not support the risk aversion hypothesis (Hypothesis 1a); however, it is consistent with the alternative view (Hypothesis 1b) and the results obtained using the balance sheet data. We also find that the impact of CEO leverage on bond maturity is economically significant. Keeping other variables unchanged at their sample means, a one-standard-deviation increase in CEO leverage is associated with a $7.5 \%$ decrease in the maturities of new debt issues. We note that the results regarding the control variables are less significant than those based on the balance sheet data, perhaps due to the smaller sample size, but are again in line with those reported in Brockman et al. (2010). Specifically, firm size, firm size squared, and firm leverage become statistically insignificant, while market-to-book is statistically significant but has an unexpected sign. On the other hand, the coefficients on asset maturity and asset volatility have the expected signs and are statistically significant.

\section{[Insert Table 9 about here]}

Turning to columns 2-4, we control for year, issue-type, and industry effects, respectively. In column 5, we control for year, issue-type, and industry effects together. The results in these four columns are consistent with the baseline regression results. That is, CEO leverage has a significantly negative effect on bond maturity. In columns 6 and 7, we consider two consolidated samples to deal with firms with multiple issues throughout the year 
(Brockman et al., 2010). In the first consolidated sample, we use these firms' annual (equalweighted) average maturity of multiple debt issues as the dependent variable. In the second sample, we use the issue-size-weighted average maturity. The results in columns 6 and 7 are qualitatively similar to those for the unconsolidated sample in column 1.

\subsubsection{Robustness Checks}

In Table 10 we examine the robustness of the results for new debt issues by using alternative measures of CEO inside debt holdings (columns 1-3) or controlling for CEO incentive compensation, including CEO delta and CEO vega (column 4), CEO stock ownership (column 5), and CFO inside debt holdings (column 6), in our regressions. The results across the models are consistent with those obtained using the balance sheet data. In columns 1-3, while CEO pensions have a significantly negative effect on the maturities of new debt issues, deferred compensation has little effect. In columns 3-6, the impact of CEO leverage on debt maturity is robust to controlling for CEO delta and CEO vega, CEO stock ownership, and CFO leverage.

[Insert Table 10 about here]

Using the lagged value of CEO leverage in the new debt issue setting helps alleviate the potential endogeneity problem. However, in column 7, we further deal with this concern by estimating a two-stage GMM model, and use the natural logarithm of $C E O$ age and the industry-median CEO leverage as instruments for a firm's CEO leverage. The second-stage GMM results show that our instruments for CEO leverage are valid and that the impact of CEO leverage on the maturities of new debt issues remains negative and statistically significant.

Overall, we find robust evidence of a negative relation between CEO inside debt holdings and the maturities of new debt issues, which is again in line with Hypothesis $1 \mathrm{~b}$. 


\subsection{Cost of New Debt Issues}

In the final analysis, we examine the interaction of CEO inside debt, bond maturity, and yield spreads. We predict that CEO leverage leads to a lower cost of debt because it mitigates managerial risk-taking and improves debt contract terms (Anantharaman et al., 2014). This analysis allows us to further examine the alternative view that firms with CEO inside debt can take advantage of the resulting lower refinancing risk and in particular lower yield spreads by issuing bonds with shorter maturities, which provides further cost savings. In addition, together with the results conditional on financial constraints in Section 4.1.4, this analysis helps rule out the possibility that our evidence of a positive effect of CEO inside debt on short-maturity debt may reflect creditors' preference for lending short-term debt rather than the borrowing firms' choice of debt maturity. If the increase in a firm's use of short-term debt were the result of its limited access to debt markets or external creditors' concerns about its risk profile, CEO leverage would be positively related to yield spreads.

To examine the relations among CEO leverage, bond maturity, and the bond yield spread, we use the following model:

$$
\begin{aligned}
& \text { Spread }_{i t}=\gamma_{0}+\gamma_{1} \operatorname{Ln}\left(\text { Bond_Mat }_{i t}+\gamma_{2} C E O_{-} L\right. \text { Leverage } \\
& i, t-1 \\
&+\gamma_{3} \operatorname{Ln}(\text { Bond_Mat })_{i t} \times C E O_{-} L \text { everage } e_{i, t-1}+\boldsymbol{\omega}^{\prime} \boldsymbol{Z}_{i, t-1}+\varepsilon_{i t},
\end{aligned}
$$

where the bond yield spread, Spread, is measured as the difference between corporate bond yield to maturity (YTM) and the YTM of a Treasury bond with similar maturity. Following Brockman et al. (2010), we control for both issue and firm characteristics, including monthly stock return standard deviation, average daily returns, average rating, return on sales, firm leverage, interest coverage ratio, issue size, euro-Treasury spread (i.e., difference between three-month euro yields and Treasury rates), and term structure; see Appendix 2 for detailed variable definitions. Since the test variables, bond maturity and CEO leverage, are likely to be determined jointly with the dependent variable, the bond yield spread, we use the GMM 
estimator with instruments to address this endogeneity concern. For brevity, we report the second-stage GMM regression results in Table 11.

\section{[Insert Table 11 about here]}

In column 1, we regress the bond yield spread on the bond maturity and the controls. Following Brockman et al. (2010), we instrument the bond maturity using firm size and size squared, which are associated with the maturities of new debt issues but not included in the bond yield spread equation. We find that the effect of the bond maturity on the bond yield spread is significantly positive, suggesting that the cost of debt decreases as firms shorten their debt maturity. This finding supports our arguments regarding the important cost-saving advantage of short-term debt and is consistent with previous evidence in the literature (Edwards et al., 2007; Brockman et al., 2010; Bao et al., 2011).

In column 2, we add CEO leverage as a test variable and, as in previous sections, use CEO age (in natural logarithm) and industry-median CEO leverage as instruments for CEO leverage. The second-stage GMM results show that CEO inside debt has a negative and statistically significant effect on the bond yield spread. The coefficient on CEO leverage is also economically significant (-0.008). Keeping other variables unchanged at their sample means, increasing CEO leverage by one standard deviation (0.495) reduces the bond yield spread by 40 basis points, which represents a $32.3 \%$ (44\%) decrease relative to the mean (median) of the bond yield spread variable. ${ }^{16}$ This evidence is consistent with the view that CEO inside debt aligns the interests of managers and external creditors and reduces risktaking incentives, leading to a lower cost of debt (Anantharaman et al., 2014).

As in Brockman et al. (2010), we next include the interaction term between bond maturity and CEO leverage in our model. In column 3, the stand-alone coefficient on $C E O$

\footnotetext{
16 The standard deviation of CEO leverage in the bond yield spread equation is different from the statistic reported in Table 1 for the larger balance sheet sample.
} 
leverage becomes significantly positive $(0.037) .{ }^{17}$ However, the effect of CEO inside debt holdings on the cost of debt, given by the partial derivative of the bond yield spread with respect to CEO leverage, $0.037-0.021 \times \operatorname{Ln}(\text { Bond_Mat })_{i t}$, remains significantly negative $(-0.007)$ at the mean bond maturity. ${ }^{18}$ This effect is economically significant and similar to the effect of CEO leverage on the cost of debt captured in column 2. Next, the impact of bond maturity on yield spreads is given by $0.016-0.021 \times C_{E O}$ Leverage $_{i, t-1}$, which at the mean CEO leverage (0.633) is equal to 0.003. Put differently, holding other variables fixed at their sample means, a one-standard-deviation increase in bond maturity (0.827) results in a 22 basis point increase in yield spreads. This result shows that (1) bonds with shorter maturities have lower yield spreads and (2) given the same debt maturity, a higher level of CEO leverage helps reduce the cost of debt.

Overall, the above results provide further support for the mechanism explaining the positive relation between CEO inside debt and short-term debt, as predicted by Hypothesis 1b. While CEO inside debt reduces the average cost of debt, ${ }^{19}$ it incentivizes managers to take on more short-maturity debt that provides further cost savings and benefits (e.g., reduction in the agency costs of debt). Put simply, managers with inside debt benefit most from the decrease in the cost of debt by using more short-term borrowings.

\footnotetext{
${ }^{17}$ We note that the flipping of the sign of the coefficient on CEO leverage in column 3, which includes an interaction term between CEO leverage and bond maturity, is similar to Brockman et al.'s (2010) results regarding CEO delta and CEO vega, whose coefficients' signs also flip in models including their interaction terms with the bond maturity.

${ }^{18}$ The mean bond maturity (in natural logarithm) in the bond yield spread equation (2.081) is slightly higher than that in the maturity equation reported in Table 9.

${ }^{19}$ In an additional analysis (untabulated), we examine whether CEO inside debt has differential effects on the costs of short-term and long-term debt. We find a significant and negative effect of CEO inside debt on the cost of short-term debt but an insignificant effect on the cost of long-term debt. This evidence is consistent with our argument, although we refrain from drawing further inference from these results due to the small sample size.
} 


\section{Conclusions}

Agency theory suggests that CEO inside debt is an important component of executive compensation, which aligns the interests of managers and creditors and restrains managerial risk-seeking behavior. In this paper, we examine the relation between CEO inside debt holdings and corporate debt maturity structure. We test two competing views regarding the impact of CEO leverage on short-term debt. On one hand, the risk aversion hypothesis predicts that managers with inside debt pursue less risky corporate policies, thus favoring the choice of long-term debt that does not expose them to refinancing risk. On the other hand, the alternative view argues that CEO inside debt facilitates access to external debt financing and alleviates the refinancing risk of short-term debt, leading to a more favorable debt contracting environment and hence a preference for the less costly shorter term debt.

Using both the balance sheet and new debt issue data, we document a statistically robust and economically important positive relation between CEO inside debt holdings and short-term debt, which is consistent with the alternative hypothesis. Our findings are insensitive to controlling for the endogeneity of CEO inside debt and the joint determination of financial leverage and debt maturity. Our results also hold for sub-periods of declining interest rates and rate stability, thus addressing the concern that they are driven by firms' preference for short-term debt during the era of declining rates.

Our further analysis shows that the impact of CEO inside debt on debt maturity is significant only for financially unconstrained firms, which tend to have larger cash reserves and hence lower refinancing risk, as documented by recent research. This finding provides further support for the mechanism driving the positive relation between CEO inside debt and short-maturity debt. Finally, we find that CEO inside debt has a negative impact on the cost of debt financing. While CEO inside debt reduces the average cost of debt, it motivates managers to take on the less costly shorter term debt, which is consistent with our alternative 
hypothesis. These results also rule out the concern that the positive relation between CEO inside debt and short-term debt is a consequence of lenders imposing short-term debt on the borrowing firm rather than a reflection of the firm's debt maturity choice.

Overall, our study shows that managerial holdings of inside debt play an important role in determining debt maturity structure. CEO inside debt is a beneficial form of executive compensation that can incentivize managers to shorten their debt maturity, thereby saving the cost of financing and enhancing firm performance. 


\section{References}

Aivazian, V., Ge, Y., Qiu, J., 2005. Debt maturity structure and firm investment. Financial Management 34, 107-119.

Almeida, H., Campello, M., Laranjeira, B., Weisbenner, S., 2011. Corporate debt maturity and the real effects of the 2007 credit crisis. Critical Finance Review 1, 3-58.

Anantharaman, D., Fang, V., Gong, G., 2014. Inside debt and the design of corporate debt contracts. Management Science 60, 1260-1280.

Bao, J., Pan, J., Wang, J., 2011. The illiquidity of corporate bonds. Journal of Finance 66, 911-946.

Barclay, M., Marx, L., Smith, C., 2003. The joint determination of leverage and maturity. Journal of Corporate Finance 9, 149-167.

Barclay, M., Smith, C., 1995. The maturity structure of corporate debt. Journal of Finance 50, 609-631.

Barnea, A., Haugen, R., Senbet, L., 1980. A rationale for debt maturity structure and call provisions in the agency theoretic framework. Journal of Finance 35, 1223-1234.

Baum, C., Schaffer, M., Stillman, S., 2003. Instrumental variables and GMM: Estimation and testing. Stata Journal 3, 1-31.

Bebchuk, L., Jackson Jr., R., 2005. Executive pensions. Journal of Corporation Law 30, 823 855.

Billett, M., King, T., Mauer, D., 2007. Growth opportunities and the choice of leverage, debt maturity, and covenants. Journal of Finance 62, 697-730.

Black, F., Scholes, M., 1973. The pricing of options and corporate liabilities. Journal of Political Economy 81, 637-654

Brick, I., Ravid, A., 1991. Interest rate uncertainty and the optimal debt maturity structure. Journal of Financial and Quantitative Analysis 26, 63-81. 
Brockman, P., Martin, X., Unlu, E., 2010. Executive compensation and the maturity of corporate debt. Journal of Finance 65, 1123-1161.

Calomiris, C., Kahn, C., 1991. The role of demandable debt in structuring optimal banking arrangements. American Economic Review, 497-513.

Cassell, C., Huang, S., Sanchez, J., Stuart, M., 2012. Seeking safety: The relation between CEO inside debt holdings and the riskiness of firm investment and financial policies. Journal of Financial Economics 103, 588-610.

Chava, S., Purnanandam, A., 2010. CEOs versus CFOs: Incentives and corporate policies. Journal of Financial Economics 97, 263-278.

Childs, P. D., Mauer, D. C., Ott, S. H., 2005. Interactions of corporate financing and investment decisions: The effects of agency conflicts. Journal of Financial Economics 76, 667-90.

Coles, J., Daniel, N., Naveen, L., 2006. Managerial incentives and risk taking. Journal of Financial Economics 79, 431-468.

Core, J., Guay, W., 2002. Estimating the value of employee stock option portfolios and their sensitivities to price and volatility. Journal of Accounting Research 40, 613-630.

Custodio, C., Ferreira, M., Laureano, L., 2013. Why are US firms using more short-term debt? Journal of Financial Economics 108, 182-212.

Dang, V.A., Lee, E., Liu, Y., Cheng, Z., 2016. Does debt maturity affect stock price crash risk? Working paper, Alliance Manchester Business School.

Datta, S., Iskandar-Datta, M., Raman, K., 2000. Debt structure adjustments and long-run stock price performance. Journal of Financial Intermediation 9, 427-453.

Datta, S., Iskandar-Datta, M., Raman, K., 2005. Managerial stock ownership and the maturity structure of corporate debt. Journal of Finance 60, 2333-2350. 
Diamond, D., 1991. Debt maturity structure and liquidity risk. Quarterly Journal of Economics 106, 709-737.

Duchin, R., Ozbas, O., Sensoy, B. A., 2010. Costly external finance, corporate investment, and the subprime mortgage credit crisis. Journal of Financial Economics 97, 418-435.

Edmans, A., Liu, Q., 2011. Inside debt. Review of Finance 15, 75-102.

Edwards, A., Harris, L., Piwowar, M., 2007. Corporate bond market transaction costs and transparency. Journal of Finance 62, 1421-1451.

Eisdorfer, A., Giaccotto, C., White, R., 2015. Do corporate managers skimp on shareholders' dividends to protect their own retirement funds? Journal of Corporate Finance 30, $257-277$.

Fama, E., Miller, M., 1972. The Theory of Finance. New York: Holt, Rinehart, and Winston.

Faulkender, M., Petersen, M., 2006. Does the source of capital affect capital structure? Review of Financial Studies 19, 45-79.

Fazzari, S., Hubbard, G., Petersen, B., 1988. Financing constraints and corporate investment. Brookings Papers on Economic Activity 19, 141-95.

Flannery, M., 1986. Asymmetric information and risky debt maturity choice. Journal of Finance 41, 19-37.

Flannery, M., Rangan, K., 2006. Partial adjustment toward target capital structures. Journal of Financial Economics 79, 469-506.

Frank, M., Goyal, V., 2009. Capital structure decisions: Which factors are reliably important? Financial Management 38, 1-37.

Frank, M., Goyal, V., 2006. Corporate leverage adjustment: How much do managers really matter? Working paper, University of Minnesota and Hong Kong University of Science and Technology. 
Gerakos, J., 2010. CEO pensions: Disclosure, managerial power, and optimal contracting. Working paper, University of Chicago.

Gorton, G., Pennacchi, G., 1990. Financial intermediaries and liquidity creation. Journal of Finance 45, 49-71.

Guay, W., 1999. The sensitivity of CEO wealth to equity risk: An analysis of the magnitude and determinants. Journal of Financial Economics 53, 43-71.

Guedes, J., Opler, T., 1996. The determinants of the maturity of corporate debt issues. Journal of Finance 51, 1809-1833.

Hadlock, C., Pierce, J., 2010. New evidence on measuring financial constraints: Moving beyond the KZ index. Review of Financial Studies 23, 1909-1940.

Harford, J., Klasa, S., Maxwell, W., 2014. Refinancing risk and cash holdings. Journal of Finance 69, 975-1012.

He, Z., Xiong, W., 2012. Rollover risk and credit risk. Journal of Finance 67, 391-429.

Huang, R., Tan, K. J. K., Faff, R. W., 2016. CEO overconfidence and corporate debt maturity. Journal of Corporate Finance 36, 93-110.

Jensen, M., Meckling, W., 1976. Theory of the firm: Managerial behavior, agency costs, and ownership structure. Journal of Financial Economics 3, 305-360.

John, T. A., John, K., 1993. Top management compensation and capital structure. Journal of Finance 48, 949-974.

Johnson, S., 2003. Debt maturity and the effects of growth opportunities and liquidity risk on leverage. Review of Financial Studies 16, 209-236.

Kane, A., Marcus, A., McDonald, R., 1985. Policy and the rate of return premium to leverage. Journal of Financial and Quantitative Analysis 20, 479-499.

Knopf, J., Nam, J., Thornton Jr., J., 2002. The volatility and price sensitivities of managerial stock option portfolios and corporate hedging. Journal of Finance 57, 801-812. 
Leary, M., Roberts, M., 2005. Do firms rebalance their capital structure? Journal of Finance $60,2575-2619$.

Leland, H., Toft, K., 1996. Optimal capital structure, endogenous bankruptcy, and the term structure of credit spreads. Journal of Finance 51, 987-1019.

Liu, Y., Mauer, D. C., Zhang, Y., 2014. Firm cash holdings and CEO inside debt. Journal of Banking and Finance 42, 83-100.

Merton, R., 1973. Theory of rational option pricing. Bell Journal of Economics and Management Science 4, 141-183.

Myers, S., 1977. Determinants of corporate borrowing. Journal of Financial Economics 5, $147-176$.

Phan, H., 2014. Inside debt and mergers and acquisitions. Journal of Financial and Quantitative Analysis 49, 1365-1401.

Rajan, R., Winton, A., 1995. Covenants and collateral as incentives to monitor. Journal of Finance 50, 1113-1146.

Scherr, F., Hulburt, H., 2001. The debt maturity structure of small firms. Financial Management 30, 85-111.

Smith, C., Stulz, R., 1985. The determinants of firms' hedging policies. Journal of Financial and Quantitative Analysis 20, 391-405.

Strebulaev, I., 2007. Do tests of capital structure theory mean what they say? Journal of Finance 62, 1747-1787.

Stulz, R., 2000. Does financial structure matter for economic growth? A corporate finance perspective. Working paper, Ohio State University.

Sundaram, R., Yermack, D., 2007. Pay me later: inside debt and its role in managerial compensation. Journal of Finance 62, 1551-1588. 
Wei, C., Yermack, D., 2011. Investors' reactions to CEOs' inside debt incentives. Review of Financial Studies 24, 3813-3840.

Zheng, X., Ghoul, S.E., Guedhami, O., Kwok, C. C. Y., 2012. National culture and corporate debt maturity. Journal of Banking and Finance 36, 468-488. 


\section{Appendix 1}

\section{Estimating Option Values, Relative CEO Incentive, and Relative CEO Leverage}

\section{Estimating Option Values}

We use the Black-Scholes (1973) formula for valuing European call options but modify it to account for dividend payouts (Merton, 1973) to estimate a stock option's value or sensitivity to the stock price or stock return volatility.

$$
\text { Option value }=\left[S e^{-d T} N(Z)-X e^{-r T} N\left(Z-\sigma T^{\left(\frac{1}{2}\right)}\right)\right]
$$

where

$$
Z=\left[\ln \left(\frac{S}{X}\right)+T\left(r-d+\frac{\sigma^{2}}{2}\right)\right] / \sigma T^{\left(\frac{1}{2}\right)}
$$

$N=$ cumulative probability function for the normal distribution

$S=$ price of the underlying stock

$X=$ option's exercise price

$\sigma=$ expected stock return volatility over the life of the option

$r=\log$ transformation of the risk-free interest rate

$T=$ time to maturity of the option in years

$d=\log$ transformation of the expected dividend yield over the life of the option.

Similar to Core and Guay (2002), Frank and Goyal (2006), and Phan (2014), we estimate the value of unexercised options held by executives (i.e., options granted in previous years whose value is not reported) using the following inputs:

- Exercise price for unexercised options: We follow a two-step process to estimate the average exercise price for unexercised exercisable options. In the first step, we calculate the ratio of the realizable value of in-the-money exercisable options and the number of unexercised exercisable options. In the second step, we subtract this ratio 
from the fiscal year-end stock price to obtain an estimate of the average exercise price for unexercised exercisable options. Similarly, we estimate the average exercise price of unexercised unexercisable options by subtracting the ratio of the number of in-themoney unexercisable options to the number of unexercised unexercisable options from the fiscal year-end stock price.

- Maturity for unexercised exercisable options: We assume the maturity of unexercised exercisable options to be four years less than the average maturity of new option grants. In the case where no option grants are made in the year, we set their maturity at six years. In addition, we set the maturity of unexercisable options at one year less than the average maturity of new grants. If no new grants are made in the year, we set the maturity of unexercisable options at nine years.

We obtain the inputs for the stock price, risk-free rate, dividend yield, and volatility from the Compustat, CRSP, and ExecuComp databases.

\section{Relative CEO Leverage $(k)$ and Relative CEO Incentive $\left(k^{*}\right)$}

We follow Edmans and Liu (2011), Wei and Yermack (2011), Cassell et al. (2012), and Phan (2014) in calculating relative CEO leverage as follows:

$$
\begin{aligned}
\text { Relative CEO leverage } & =\left(D_{C E O} / D_{F I R M}\right) \div\left(E_{C E O} / E_{F I R M}\right) \\
& =\left(D_{C E O} / E_{C E O}\right) \div\left(D_{F I R M} / E_{F I R M}\right)
\end{aligned}
$$

where $D_{C E O}$ and $E_{C E O}$ are the CEO's inside debt and inside equity, and $D_{F I R M}$ and $E_{F I R M}$ are the total debt and equity claims, including those held by the CEO, against the company. We calculate relative CEO incentive as follows:

$$
\begin{aligned}
\text { Relative CEO incentive } & =\left(\Delta D_{C E O} / \Delta E_{C E O}\right) \div\left(\Delta D_{F I R M} / \Delta E_{F I R M}\right) \\
& =\left(\Delta D_{C E O} / \Delta D_{F I R M}\right) \div\left(\Delta E_{C E O} / \Delta E_{F I R M}\right)
\end{aligned}
$$

Because a CEO's equity consists of shares and stock options, we calculate $\Delta E_{C E O}$ as follows: 


$$
\Delta E_{C E O}=S+\sum_{i} N_{i}\left(\Delta N_{i}\right)
$$

where $S$ and $N$ are the number of shares and stock options held by the CEO, respectively. $\Delta N$ is the option delta, calculated according to the Black-Scholes option pricing model with the inputs mentioned above. CEO options are typically granted in tranches, and we index them by the subscript $i$, such that different subscripts indicate different exercise prices and times to maturity. Equation (7) reflects the total change in the CEO's equity holdings per $\$ 1.00$ change in stock price.

We follow Wei and Yermack (2011) in using the total number of employee stock options outstanding and their average exercise price reported in Compustat, and in assuming that the average remaining life of these options is four years, to estimate the delta of a representative option outstanding for each firm and the firm's total delta. We approximate the ratio $\Delta D_{C E O} / \Delta D_{F I R M}$ by

$$
\Delta D_{C E O} / \Delta D_{F I R M} \approx D_{C E O} / D_{F I R M}
$$




\section{Appendix 2}

\section{Table A.1. Variable Definitions}

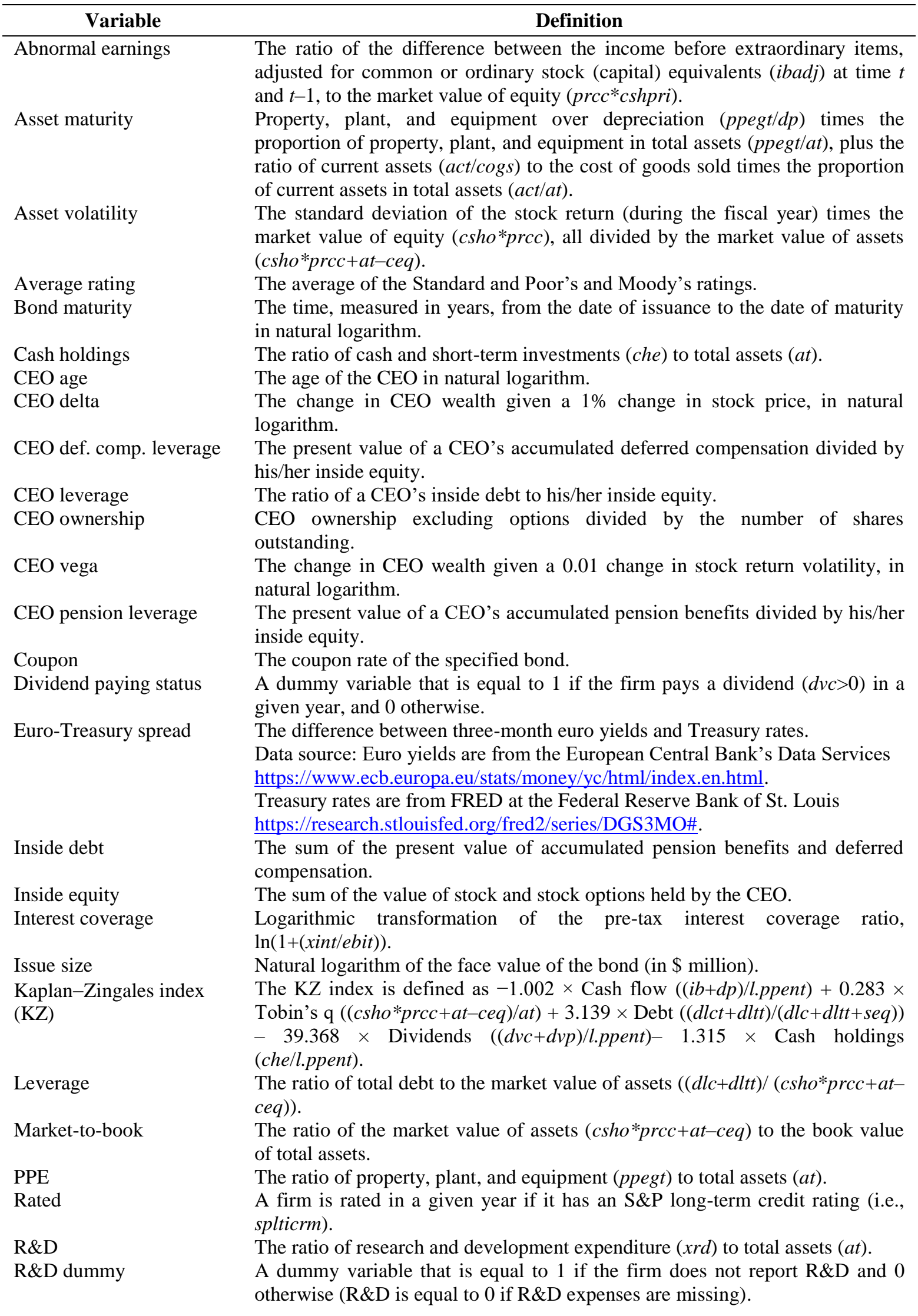


Relative CEO incentive $\left(k^{*}\right)$

Relative CEO incentive > 1 dummy ( $k^{*}$ dummy)

Relative CEO leverage $(k)$ Relative CEO leverage $>1$ dummy ( $k$ dummy)

Return std. dev.

ROS

SA

Short-term debt (ST3)

Short-term debt 1 (ST1)

Short-term debt 2 (ST2)

Short-term debt 5 (ST5)

Short-term debt NP (STNP)

Size

Spread

Term structure

The Whited-Wu index (WW)
The ratio of the marginal change in the value of CEO inside debt holdings to the marginal change in CEO inside equity holdings, given in firm value, all scaled by the firm's respective ratio.

An indicator that takes the value of 1 if the relative CEO incentive exceeds 1 and 0 otherwise.

The ratio of the CEO's debt-to-equity ratio to the firm's debt-to-equity ratio.

An indicator that takes a value of 1 if the relative CEO leverage exceeds 1 and 0 otherwise.

Monthly stock return standard deviation during the fiscal year, multiplied by the ratio of the market value of equity (csho*prcc) to the market value of assets (csho*prcc $+a t-c e q)$.

Operating income before depreciation (ebitda) scaled by sales (sale).

The size-age index, calculated as $-0.737 \times$ Size $+0.043 \times$ Size $^{2}-0.040 \times$ Age, where Size is the natural logarithm of inflation-adjusted book assets, and Age is the number of years the firm has been on Compustat with a nonmissing stock price.

The ratio of debt in current liabilities $(d l c)$ plus debt maturing in two or three years $(d d 2+d d 3)$ to total debt (the sum of debt in current liabilities plus longterm debt, i.e., $d l c+d l t t)$

The ratio of debt in current liabilities $(d l c)$ to total debt $(d l c+d l t t)$.

The ratio of debt in current liabilities $(d l c)$ plus debt maturing in two years (dd2) to total debt $(d l c+d l t t)$.

The ratio of debt in current liabilities $(d l c)$ plus debt maturing in two, three, four, or five years $(d d 2+d d 3+d d 4+d d 5)$ to total debt $(d l c+d l t t)$.

The ratio of debt in current liabilities without the current proportion of longterm debt $(n p)$ to total debt $(d l c+d l t t)$.

The market value of assets, defined as the market value of equity ( $c s h o^{*} p r c c$ ) plus the book value of total assets (at) minus the book value of equity (ceq). The variable is measured in 2006 dollars and in natural logarithm.

Corporate bond yield to maturity (YTM) minus the YTM of a Treasury bond with similar maturity.

The difference between the yield on 10-year government bonds and the yield on 6-month government bonds. Data source: FRED at the Federal Reserve Bank of St. Louis https://research.stlouisfed.org/fred2/release?rid=18.

The Whited $-\mathrm{Wu}$ index is defined as $-0.091 \times$ Cash flow $((i b+d p) / a t)-0.062$ $\times$ Dividend dummy $+0.021 \times$ Long-term debt $($ dlttlat $)-0.044 \times$ Size $(\ln (a t))+$ $0.102 \times$ Industry sales growth $-0.035 \times$ Sales growth. The Dividend dummy is equal to 1 if firms pay dividends $(d v p d>0)$ and 0 otherwise. Sales growth is measured as (sales (sale) in year $t$ minus sales in year $t-1) /($ sales in year $t-1$ ). Industry sales growth is the average sales growth of firms belonging to the same three-digit SIC-code industry. 
Table 1. Summary Statistics

\begin{tabular}{|c|c|c|c|c|c|c|}
\hline Variable & Observations & Mean & Std. dev. & $1^{\text {st }}$ Quartile & Median & $3^{\text {rd }}$ Quartile \\
\hline Short-term debt NP & 4,793 & 0.069 & 0.174 & 0.000 & 0.000 & 0.049 \\
\hline Short-term debt 1 & 4,793 & 0.151 & 0.223 & 0.010 & 0.066 & 0.182 \\
\hline Short-term debt 2 & 4,793 & 0.242 & 0.268 & 0.044 & 0.159 & 0.325 \\
\hline Short-term debt 3 & 4,793 & 0.348 & 0.300 & 0.113 & 0.273 & 0.488 \\
\hline Short-term debt 5 & 4,703 & 0.576 & 0.307 & 0.344 & 0.537 & 0.885 \\
\hline CEO leverage & 4,793 & 0.542 & 0.996 & 0.058 & 0.214 & 0.565 \\
\hline Size (in $\$$ million) & 4,793 & 18,710 & 40,724 & 2,213 & 5,749 & 17,210 \\
\hline Market-to-book & 4,793 & 1.635 & 0.710 & 1.155 & 1.416 & 1.897 \\
\hline Abnormal earnings & 4,793 & -0.022 & 0.245 & -0.014 & 0.005 & 0.019 \\
\hline Asset maturity & 4,793 & 11.849 & 10.937 & 3.473 & 7.959 & 17.290 \\
\hline Asset volatility & 4,793 & 0.055 & 0.030 & 0.033 & 0.050 & 0.070 \\
\hline Leverage & 4,793 & 0.259 & 0.188 & 0.118 & 0.220 & 0.367 \\
\hline$R \& D$ & 4,793 & 0.020 & 0.046 & 0.000 & 0.000 & 0.018 \\
\hline Term structure & 4,793 & 0.018 & 0.012 & 0.001 & 0.020 & 0.030 \\
\hline$k$ & 4,675 & 2.304 & 3.715 & 0.241 & 0.839 & 2.344 \\
\hline$k$ dummy & 4,675 & 0.455 & 0.498 & 0.000 & 0.000 & 1.000 \\
\hline$k^{*}$ & 4,675 & 1.738 & 2.847 & 0.187 & 0.622 & 1.747 \\
\hline$k^{*}$ dummy & 4,675 & 0.380 & 0.486 & 0.000 & 0.000 & 1.000 \\
\hline CEO pension leverage & 4,792 & 0.338 & 0.721 & 0.000 & 0.052 & 0.359 \\
\hline CEO def. comp. leverage & 4,791 & 0.181 & 0.356 & 0.010 & 0.057 & 0.181 \\
\hline CEO delta (in $\$$ thousand) & 4,793 & 595.316 & $1,178.62$ & 91.404 & 237.94 & 593.385 \\
\hline CEO vega (in $\$$ thousand) & 4,793 & 176.420 & 248.559 & 20.783 & 81.07 & 220.146 \\
\hline CEO ownership & 4,782 & 0.010 & 0.029 & 0.001 & 0.001 & 0.006 \\
\hline CFO leverage & 6,054 & 0.636 & 1.297 & 0.079 & 0.227 & 0.620 \\
\hline CEO age (years) & 4,793 & 56.110 & 6.153 & 52.000 & 56.00 & 60.000 \\
\hline PPE & 4,793 & 0.320 & 0.239 & 0.125 & 0.240 & 0.495 \\
\hline Bond maturity & 367 & 1.942 & 0.763 & 0.071 & 1.949 & 3.404 \\
\hline Bond spread & 211 & 0.012 & 0.001 & 0.007 & 0.009 & 0.013 \\
\hline
\end{tabular}

The table reports the summary statistics (i.e., the number of observations, mean, standard deviation (std. dev.), first quartile, median, and third quartile) of the variables. Our sample covers 2006-2012. Financial firms (with SIC codes 6,000-6,999) and utilities (with SIC codes 4,900-4,999) are excluded. Variable definitions are provided in Table A.1 in Appendix 2. 
Table 2. CEO Inside Debt and Short-term Debt: Baseline Regressions

\begin{tabular}{|c|c|c|c|c|c|c|c|c|c|}
\hline Variable & OLS & OLS & $\begin{array}{c}\text { OLS in first } \\
\text { differences - } \\
\text { change reg. } \\
\text { (3) }\end{array}$ & $\begin{array}{c}\text { OLS with } \\
\text { year effects } \\
(4) \\
\end{array}$ & $\begin{array}{c}\text { OLS with } \\
\text { industry effects } \\
(5)\end{array}$ & $\begin{array}{l}\text { OLS with year } \\
\text { and industry } \\
\text { effects } \\
(6)\end{array}$ & $\begin{array}{c}\text { Tobit with firm } \\
\text { fixed effects } \\
(7)\end{array}$ & $\begin{array}{c}\text { Firm fixed } \\
\text { effects } \\
(8) \\
\end{array}$ & $\begin{array}{c}\text { Firm, } \\
\text { industry, and } \\
\text { year effects } \\
(9)\end{array}$ \\
\hline \multirow[t]{2}{*}{ CEO leverage } & & $0.019 * * *$ & $0.012 * *$ & $0.017 * * *$ & $0.015^{* *}$ & $0.014 * * *$ & $0.015^{* * *}$ & $0.013 * *$ & $0.012 *$ \\
\hline & & $(0.006)$ & $(0.005)$ & $(0.006)$ & $(0.006)$ & $(0.005)$ & $(0.005)$ & $(0.006)$ & $(0.007)$ \\
\hline \multirow[t]{2}{*}{ Size } & $-0.325 * * *$ & $-0.319 * * *$ & -0.159 & $-0.314 * * *$ & $-0.328 * * *$ & $-0.325 * * *$ & $-0.396 * * *$ & $-0.325 * * *$ & $-0.321 * * *$ \\
\hline & $(0.040)$ & $(0.040)$ & $(0.138)$ & $(0.040)$ & $(0.040)$ & $(0.030)$ & $(0.046)$ & $(0.110)$ & $(0.110)$ \\
\hline \multirow[t]{2}{*}{ Size squared } & $0.016^{* * *}$ & $0.016 * * *$ & 0.005 & $0.015 * * *$ & $0.017 * * *$ & $0.016 * * *$ & $0.020 * * *$ & $0.015 * *$ & $0.016 * *$ \\
\hline & $(0.002)$ & $(0.002)$ & $(0.007)$ & $(0.002)$ & $(0.002)$ & $(0.002)$ & $(0.003)$ & $(0.006)$ & $(0.006)$ \\
\hline \multirow[t]{2}{*}{ Market-to-book } & 0.017 & 0.018 & 0.024 & 0.019 & 0.017 & $0.018 * *$ & 0.013 & $0.030^{*}$ & $0.028 *$ \\
\hline & $(0.012)$ & $(0.012)$ & $(0.022)$ & $(0.012)$ & $(0.012)$ & $(0.008)$ & $(0.010)$ & $(0.016)$ & $(0.016)$ \\
\hline \multirow[t]{2}{*}{ Abnormal earnings } & $-0.085^{* * *}$ & $-0.070 * * *$ & -0.014 & $-0.066 * * *$ & $-0.078 * * *$ & $-0.072 * * *$ & $-0.071 * * *$ & 0.001 & 0.000 \\
\hline & $(0.019)$ & $(0.020)$ & $(0.019)$ & $(0.020)$ & $(0.020)$ & $(0.021)$ & $(0.017)$ & $(0.005)$ & $(0.005)$ \\
\hline \multirow[t]{2}{*}{ Asset maturity } & $-0.002 * * *$ & $-0.003 * * *$ & 0.002 & $-0.002 * * *$ & $-0.002 * * *$ & $-0.002 * * *$ & $-0.002 * * *$ & -0.000 & 0.000 \\
\hline & $(0.001)$ & $(0.001)$ & $(0.002)$ & $(0.001)$ & $(0.001)$ & $(0.000)$ & $(0.001)$ & $(0.002)$ & $(0.002)$ \\
\hline \multirow[t]{2}{*}{ Asset volatility } & -0.089 & -0.001 & -0.123 & -0.352 & 0.362 & 0.011 & 0.209 & -0.128 & $-0.397 *$ \\
\hline & $(0.224)$ & $(0.225)$ & $(0.264)$ & $(0.245)$ & $(0.225)$ & $(0.223)$ & $(0.191)$ & $(0.209)$ & $(0.235)$ \\
\hline \multirow[t]{2}{*}{ Leverage } & $-0.320 * * *$ & $-0.333 * * *$ & $-0.237 * * *$ & $-0.352 * * *$ & $-0.318 * * *$ & $-0.334 * * *$ & $-0.348 * * *$ & $-0.216^{* * *}$ & $-0.234 * * *$ \\
\hline & $(0.047)$ & $(0.047)$ & $(0.076)$ & $(0.047)$ & $(0.048)$ & $(0.033)$ & $(0.040)$ & $(0.058)$ & $(0.062)$ \\
\hline \multirow[t]{2}{*}{ R\&D } & 0.253 & 0.243 & 0.094 & 0.243 & $0.399 *$ & $0.402 * * *$ & 0.213 & -0.109 & -0.128 \\
\hline & $(0.164)$ & $(0.164)$ & $(0.263)$ & $(0.164)$ & $(0.223)$ & $(0.149)$ & $(0.162)$ & $(0.392)$ & $(0.392)$ \\
\hline \multirow[t]{2}{*}{ R\&D dummy } & $0.026 *$ & $0.026 *$ & -0.059 & $0.025 *$ & -0.001 & -0.001 & 0.003 & $-0.094 * *$ & $-0.095 * *$ \\
\hline & $(0.014)$ & $(0.014)$ & $(0.072)$ & $(0.014)$ & $(0.018)$ & $(0.012)$ & $(0.016)$ & $(0.044)$ & $(0.044)$ \\
\hline \multirow[t]{2}{*}{ Term structure } & $2.364 * * *$ & $2.233 * * *$ & $3.672 * * *$ & 5.868 & $1.963 * * *$ & $4.637 * * *$ & $2.319 * * *$ & $2.197 * * *$ & 2.048 \\
\hline & $(0.399)$ & $(0.403)$ & $(0.590)$ & $(6.003)$ & $(0.396)$ & $(1.347)$ & $(0.359)$ & $(0.375)$ & $(6.656)$ \\
\hline \multirow[t]{2}{*}{ Constant } & $1.942 * * *$ & $1.903 * * *$ & $-0.013 * * *$ & $1.909 * * *$ & $1.907 * * *$ & $1.816^{* * *}$ & $2.278 * * *$ & $2.032 * * *$ & $1.963 * * *$ \\
\hline & $(0.178)$ & $(0.177)$ & $(0.004)$ & $(0.176)$ & $(0.177)$ & $(0.139)$ & $(0.197)$ & $(0.478)$ & $(0.479)$ \\
\hline Year effects & No & No & No & Yes & No & Yes & No & No & Yes \\
\hline Industry effects & No & No & No & No & Yes & Yes & No & No & No \\
\hline Firm fixed effects & No & No & No & No & No & No & Yes & Yes & Yes \\
\hline Observations & 4,793 & 4,793 & 3,685 & 4,793 & 4,793 & 4,793 & 4,793 & 4,793 & 4,793 \\
\hline Adj. R-squared & 0.140 & 0.144 & 0.023 & 0.151 & 0.187 & 0.193 & & 0.024 & 0.028 \\
\hline
\end{tabular}

The table reports the estimates of OLS, first-differences (change), and (Tobit) fixed-effects regressions of short-term debt, defined as the fraction of debt maturing within three years (ST3), on CEO leverage and the control variables. Variable definitions are provided in Table A.1 in Appendix 2. Heteroskedasticity-robust standard errors adjusted for firm-level clustering are given in parentheses. *, **, and $* * *$ indicate significance of the coefficients at the $10 \%, 5 \%$, and $1 \%$ levels, respectively. 
Table 3. Short-term Debt and Alternative Measures of CEO Inside Debt

\begin{tabular}{|c|c|c|c|c|c|c|c|}
\hline Variable & $(1)$ & $(2)$ & $(3)$ & $(4)$ & $(5)$ & $(6)$ & $(7)$ \\
\hline CEO pension leverage & $\begin{array}{l}0.023 * * * \\
(0.008)\end{array}$ & & $\begin{array}{l}0.021 * * \\
(0.009)\end{array}$ & & & & \\
\hline CEO def. comp. leverage & & $\begin{array}{l}0.022 \\
(0.014)\end{array}$ & $\begin{array}{l}0.014 \\
(0.015)\end{array}$ & & & & \\
\hline$k$ & & & & $\begin{array}{l}0.010 * * * \\
(0.002)\end{array}$ & & & \\
\hline$k^{*}$ & & & & & $\begin{array}{l}0.013 * * * \\
(0.003)\end{array}$ & & \\
\hline$k$ dummy & & & & & & $\begin{array}{l}0.039 * * * \\
(0.012)\end{array}$ & \\
\hline$k^{*}$ dummy & & & & & & & $\begin{array}{l}0.035 * * * \\
(0.012)\end{array}$ \\
\hline Size & $\begin{array}{l}-0.325^{* * *} \\
(0.040)\end{array}$ & $\begin{array}{l}-0.320 * * * \\
(0.040)\end{array}$ & $\begin{array}{l}-0.322 * * * \\
(0.041)\end{array}$ & $\begin{array}{l}-0.292 * * * \\
(0.040)\end{array}$ & $\begin{array}{l}-0.292 * * * \\
(0.040)\end{array}$ & $\begin{array}{l}-0.314 * * * \\
(0.040)\end{array}$ & $\begin{array}{l}-0.313 * * * \\
(0.040)\end{array}$ \\
\hline Size squared & $\begin{array}{l}0.016 * * * \\
(0.002)\end{array}$ & $\begin{array}{l}0.016 * * * \\
(0.002)\end{array}$ & $\begin{array}{l}0.016 * * * \\
(0.002)\end{array}$ & $\begin{array}{l}0.014 * * * \\
(0.002)\end{array}$ & $\begin{array}{l}0.014 * * * \\
(0.002)\end{array}$ & $\begin{array}{l}0.015 * * * \\
(0.002)\end{array}$ & $\begin{array}{l}0.015 * * * \\
(0.002)\end{array}$ \\
\hline Market-to-book & $\begin{array}{l}0.018 \\
(0.012)\end{array}$ & $\begin{array}{l}0.017 \\
(0.012)\end{array}$ & $\begin{array}{l}0.019 \\
(0.012)\end{array}$ & $\begin{array}{l}0.016 \\
(0.012)\end{array}$ & $\begin{array}{l}0.016 \\
(0.012)\end{array}$ & $\begin{array}{l}0.020 \\
(0.012)\end{array}$ & $\begin{array}{l}0.019 \\
(0.012)\end{array}$ \\
\hline Abnormal earnings & $\begin{array}{l}-0.077 * * * \\
(0.020)\end{array}$ & $\begin{array}{l}-0.080^{* * * *} \\
(0.019)\end{array}$ & $\begin{array}{l}-0.074 * * * \\
(0.020)\end{array}$ & $\begin{array}{l}-0.072 * * * \\
(0.020)\end{array}$ & $\begin{array}{l}-0.072 * * * \\
(0.020)\end{array}$ & $\begin{array}{l}-0.078 * * * \\
(0.020)\end{array}$ & $\begin{array}{l}-0.079 * * * \\
(0.020)\end{array}$ \\
\hline Asset maturity & $\begin{array}{l}-0.003 * * * \\
(0.001)\end{array}$ & $\begin{array}{l}-0.002 * * * \\
(0.001)\end{array}$ & $\begin{array}{l}-0.003 \text { *** } \\
(0.001)\end{array}$ & $\begin{array}{l}-0.003 \text { *** } \\
(0.001)\end{array}$ & $\begin{array}{l}-0.003 * * * \\
(0.001)\end{array}$ & $\begin{array}{l}-0.003 * * * \\
(0.001)\end{array}$ & $\begin{array}{l}-0.003 * * * \\
(0.001)\end{array}$ \\
\hline Asset volatility & $\begin{array}{l}-0.013 \\
(0.224)\end{array}$ & $\begin{array}{l}-0.059 \\
(0.225)\end{array}$ & $\begin{array}{l}0.001 \\
(0.225)\end{array}$ & $\begin{array}{l}-0.039 \\
(0.224)\end{array}$ & $\begin{array}{l}-0.066 \\
(0.224)\end{array}$ & $\begin{array}{l}-0.034 \\
(0.226)\end{array}$ & $\begin{array}{l}-0.060 \\
(0.227)\end{array}$ \\
\hline Leverage & $\begin{array}{l}-0.331 * * * \\
(0.047)\end{array}$ & $\begin{array}{l}-0.323 * * * \\
(0.047)\end{array}$ & $\begin{array}{l}-0.332 * * * \\
(0.047)\end{array}$ & $\begin{array}{l}-0.243 * * * \\
(0.045)\end{array}$ & $\begin{array}{l}-0.244 * * * \\
(0.045)\end{array}$ & $\begin{array}{l}-0.277 * * * \\
(0.047)\end{array}$ & $\begin{array}{l}-0.286 * * * \\
(0.047)\end{array}$ \\
\hline $\mathrm{R} \& \mathrm{D}$ & $\begin{array}{l}0.244 \\
(0.165)\end{array}$ & $\begin{array}{l}0.246 \\
(0.163)\end{array}$ & $\begin{array}{l}0.240 \\
(0.164)\end{array}$ & $\begin{array}{l}0.209 \\
(0.163)\end{array}$ & $\begin{array}{l}0.216 \\
(0.163)\end{array}$ & $\begin{array}{l}0.232 \\
(0.164)\end{array}$ & $\begin{array}{l}0.233 \\
(0.163)\end{array}$ \\
\hline R\&D dummy & $\begin{array}{l}0.027 * * \\
(0.014)\end{array}$ & $\begin{array}{l}0.026^{*} \\
(0.014)\end{array}$ & $\begin{array}{l}0.027 * * \\
(0.014)\end{array}$ & $\begin{array}{l}0.029 * * \\
(0.014)\end{array}$ & $\begin{array}{l}0.028 * * \\
(0.014)\end{array}$ & $\begin{array}{l}0.030 * * \\
(0.014)\end{array}$ & $\begin{array}{l}0.030 * * \\
(0.014)\end{array}$ \\
\hline Term structure & $\begin{array}{l}2.255^{* * * *} \\
(0.401)\end{array}$ & $\begin{array}{l}2.296 * * * \\
(0.403)\end{array}$ & $\begin{array}{l}2.212 * * * \\
(0.403)\end{array}$ & $\begin{array}{l}2.072 * * * \\
(0.409)\end{array}$ & $\begin{array}{l}2.086 * * * \\
(0.409)\end{array}$ & $\begin{array}{l}2.180 * * * \\
(0.408)\end{array}$ & $\begin{array}{l}2.236 * * * \\
(0.407)\end{array}$ \\
\hline Constant & $\begin{array}{l}1.933 * * * \\
(0.178)\end{array}$ & $\begin{array}{l}1.918 * * * \\
(0.179)\end{array}$ & $\begin{array}{l}1.919 * * * \\
(0.179)\end{array}$ & $\begin{array}{l}1.764 * * * \\
(0.177)\end{array}$ & $\begin{array}{l}1.766 * * * \\
(0.177)\end{array}$ & $\begin{array}{l}1.870 * * * \\
(0.178)\end{array}$ & $\begin{array}{l}1.874 * * * \\
(0.178)\end{array}$ \\
\hline Observations & 4,792 & 4,791 & 4,790 & 4,675 & 4,675 & 4,675 & 4,675 \\
\hline Adj. R-squared & 0.143 & 0.141 & 0.144 & 0.158 & 0.158 & 0.149 & 0.148 \\
\hline
\end{tabular}

The table reports the estimates of OLS regressions of short-term debt, defined as debt maturing within three years (ST3), on alternative measures of CEO inside debt and the control variables. Variable definitions are provided in Table A.1 in Appendix 2. Heteroskedasticity-robust standard errors adjusted for firm-level clustering are given in parentheses. *, **, and $* * *$ indicate significance of the coefficients at the $10 \%, 5 \%$, and $1 \%$ levels, respectively. 
Table 4. CEO Inside Debt and Alternative Measures of Short-term Debt

\begin{tabular}{|c|c|c|c|c|}
\hline Variable & $\begin{array}{c}\text { ST1 } \\
(1) \\
\end{array}$ & $\begin{array}{c}\text { ST2 } \\
(2) \\
\end{array}$ & $\begin{array}{c}\text { ST5 } \\
(4) \\
\end{array}$ & $\begin{array}{c}\text { STNP } \\
(5) \\
\end{array}$ \\
\hline \multirow[t]{2}{*}{ CEO leverage } & $0.020 * * *$ & $0.019 * * *$ & 0.001 & $0.018 * * *$ \\
\hline & $(0.005)$ & $(0.006)$ & $(0.006)$ & $(0.005)$ \\
\hline \multirow[t]{2}{*}{ Size } & $-0.168 * * *$ & $-0.261 * * *$ & $-0.303 * * *$ & $-0.109 * * *$ \\
\hline & $(0.037)$ & $(0.038)$ & $(0.041)$ & $(0.034)$ \\
\hline \multirow[t]{2}{*}{ Size squared } & $0.009 * * *$ & $0.013 * * *$ & $0.014 * * *$ & $0.006 * * *$ \\
\hline & $(0.002)$ & $(0.002)$ & $(0.002)$ & $(0.002)$ \\
\hline \multirow[t]{2}{*}{ Market-to-book } & 0.009 & 0.016 & $0.031 * *$ & 0.004 \\
\hline & $(0.010)$ & $(0.011)$ & $(0.012)$ & $(0.009)$ \\
\hline \multirow[t]{2}{*}{ Abnormal earnings } & $-0.068 * * *$ & $-0.069 * * *$ & $-0.064 * * *$ & $-0.022 *$ \\
\hline & $(0.016)$ & $(0.018)$ & $(0.018)$ & $(0.012)$ \\
\hline \multirow[t]{2}{*}{ Asset maturity } & $-0.001 *$ & $-0.001 * *$ & $-0.005^{* * *}$ & -0.000 \\
\hline & $(0.000)$ & $(0.000)$ & $(0.001)$ & $(0.000)$ \\
\hline \multirow[t]{2}{*}{ Asset volatility } & $-0.281 *$ & -0.288 & $0.458 * *$ & $-0.283 * *$ \\
\hline & $(0.154)$ & $(0.196)$ & $(0.227)$ & $(0.131)$ \\
\hline \multirow[t]{2}{*}{ Leverage } & $-0.283 * * *$ & $-0.354 * * *$ & $-0.161 * * *$ & $-0.150 * * *$ \\
\hline & $(0.035)$ & $(0.041)$ & $(0.047)$ & $(0.030)$ \\
\hline \multirow[t]{2}{*}{$\mathrm{R} \& \mathrm{D}$} & $0.387 * * *$ & $0.333 * *$ & 0.061 & $0.239 *$ \\
\hline & $(0.138)$ & $(0.158)$ & $(0.175)$ & $(0.142)$ \\
\hline \multirow[t]{2}{*}{ R\&D dummy } & 0.015 & $0.023 *$ & $0.034 * *$ & 0.010 \\
\hline & $(0.011)$ & $(0.012)$ & $(0.015)$ & $(0.009)$ \\
\hline \multirow[t]{2}{*}{ Term structure } & -0.493 & $0.827 * *$ & $0.773 *$ & -0.186 \\
\hline & $(0.308)$ & $(0.369)$ & $(0.422)$ & $(0.268)$ \\
\hline \multirow[t]{2}{*}{ Constant } & $1.008 * * *$ & $1.536 * * *$ & $2.127 * * *$ & $0.620 * * *$ \\
\hline & $(0.162)$ & $(0.169)$ & $(0.179)$ & $(0.151)$ \\
\hline Observations & 5,266 & 4,804 & 4,703 & 5,263 \\
\hline Adj. R-squared & 0.099 & 0.122 & 0.192 & 0.050 \\
\hline
\end{tabular}

The table reports the estimates of OLS regressions using alternative measures of short-term debt, including short-term debt that matures within one (ST1), two (ST2), and five years (ST5), as well as debt due in one year net of the current proportion of long-term debt $(S T N P)$. Variable definitions are provided in Table A.1 in Appendix 2. Heteroskedasticity-robust standard errors adjusted for firm-level clustering are given in parentheses. *, **, and $* * *$ indicate significance of the coefficients at the $10 \%, 5 \%$, and $1 \%$ levels, respectively. 
Table 5. CEO Inside Debt and Short-term Debt: Controlling for CEO Performancebased Compensation, CEO Ownership, and CFO Inside Debt

\begin{tabular}{|c|c|c|c|}
\hline Variable & (1) & $(2)$ & (3) \\
\hline \multirow[t]{2}{*}{ CEO leverage } & $0.012 * *$ & $0.020 * * *$ & $0.010^{*}$ \\
\hline & $(0.005)$ & $(0.006)$ & $(0.005)$ \\
\hline \multirow[t]{2}{*}{ CEO delta } & $-0.016 * * *$ & & \\
\hline & $(0.005)$ & & \\
\hline \multirow[t]{2}{*}{ CEO vega } & $0.008 * *$ & & \\
\hline & $(0.004)$ & & \\
\hline \multirow[t]{2}{*}{ CEO ownership } & & $0.370^{*}$ & \\
\hline & & $(0.197)$ & \\
\hline \multirow[t]{2}{*}{ CFO leverage } & & & $0.010 * *$ \\
\hline & & & $(0.004)$ \\
\hline \multirow[t]{2}{*}{ Size } & $-0.309 * * *$ & $-0.309 * * *$ & $-0.332 * * *$ \\
\hline & $(0.031)$ & $(0.040)$ & $(0.035)$ \\
\hline \multirow[t]{2}{*}{ Size squared } & $0.015 * * *$ & $0.015 * * *$ & $0.016 * * *$ \\
\hline & $(0.002)$ & $(0.002)$ & $(0.002)$ \\
\hline \multirow[t]{2}{*}{ Market-to-book } & $0.018 * *$ & 0.017 & 0.015 \\
\hline & $(0.008)$ & $(0.012)$ & $(0.010)$ \\
\hline \multirow[t]{2}{*}{ Abnormal earnings } & $-0.085 * * *$ & $-0.068 * * *$ & $0.021 *$ \\
\hline & $(0.022)$ & $(0.020)$ & $(0.011)$ \\
\hline \multirow[t]{2}{*}{ Asset maturity } & $-0.002 * * *$ & $-0.002 * * *$ & $-0.003 * * *$ \\
\hline & $(0.000)$ & $(0.001)$ & $(0.000)$ \\
\hline \multirow[t]{2}{*}{ Asset volatility } & 0.093 & -0.004 & -0.117 \\
\hline & $(0.194)$ & $(0.225)$ & $(0.214)$ \\
\hline \multirow[t]{2}{*}{ Leverage } & $-0.372 * * *$ & $-0.335 * * *$ & $-0.324 * * *$ \\
\hline & $(0.033)$ & $(0.047)$ & $(0.037)$ \\
\hline \multirow[t]{2}{*}{$\mathrm{R} \& \mathrm{D}$} & $0.213 *$ & 0.256 & 0.210 \\
\hline & $(0.116)$ & $(0.164)$ & $(0.132)$ \\
\hline \multirow[t]{2}{*}{ R\&D dummy } & $0.026 * * *$ & $0.025^{*}$ & $0.027 * *$ \\
\hline & $(0.010)$ & $(0.014)$ & $(0.011)$ \\
\hline \multirow[t]{2}{*}{ Term structure } & $2.035 * * *$ & $2.248 * * *$ & $1.847 * * *$ \\
\hline & $(0.389)$ & $(0.404)$ & $(0.399)$ \\
\hline \multirow[t]{2}{*}{ Constant } & $1.909 * * *$ & $1.855^{* * *}$ & $1.989 * * *$ \\
\hline & $(0.138)$ & $(0.177)$ & $(0.161)$ \\
\hline Observations & 4,405 & 4,782 & 3,367 \\
\hline Adj. R-squared & 0.152 & 0.144 & 0.133 \\
\hline
\end{tabular}

The table reports the estimates of OLS regressions of short-term debt (ST3), controlling for the effects of CEO performance-based compensation (measured by $C E O$ delta and $C E O$ vega), CEO ownership (measured by $C E O$ ownership), and CFO leverage. Variable definitions are provided in Table A.1 in Appendix 2. Heteroskedasticity-robust standard errors adjusted for firm-level clustering are given in parentheses. *, **, and $* * *$ indicate significance of the coefficients at the $10 \%, 5 \%$, and $1 \%$ levels, respectively. 
Table 6. CEO Inside Debt and Short-term Debt: Controlling for Simultaneity and Endogeneity

\begin{tabular}{|c|c|c|c|c|c|c|c|}
\hline \multirow[b]{2}{*}{ Variable } & \multicolumn{2}{|c|}{ (1) } & \multicolumn{2}{|c|}{ (2) } & \multicolumn{3}{|c|}{ (3) } \\
\hline & $\begin{array}{c}1^{\text {st }} \text { stage } \\
\text { Leverage as } \\
\text { dep. variable }\end{array}$ & $2^{\text {nd }}$ stage & $\begin{array}{c}1^{\text {st }} \text { stage } \\
\text { CEO leverage as } \\
\text { dep. variable }\end{array}$ & $2^{\text {nd }}$ stage & $\begin{array}{c}1^{\text {st }} \text { stage } \\
\text { Leverage as } \\
\text { dep. variable }\end{array}$ & $\begin{array}{c}1^{\text {st }} \text { stage } \\
\text { CEO leverage as } \\
\text { dep. variable }\end{array}$ & $2^{\text {nd }}$ stage \\
\hline CEO leverage & $\begin{array}{l}0.015 * * * \\
(0.003)\end{array}$ & $\begin{array}{l}0.032 * * * \\
(0.006)\end{array}$ & & $\begin{array}{l}0.051 * * * \\
(0.015)\end{array}$ & & & $\begin{array}{l}0.083 * * * \\
(0.020)\end{array}$ \\
\hline Size & $\begin{array}{l}0.090 * * * \\
(0.014)\end{array}$ & $\begin{array}{l}-0.230 * * * \\
(0.041)\end{array}$ & $\begin{array}{l}-0.380 * * * \\
(0.106)\end{array}$ & $\begin{array}{l}-0.300 * * * \\
(0.029)\end{array}$ & $\begin{array}{l}0.084 * * * \\
(0.014)\end{array}$ & $\begin{array}{l}-0.338 * * * \\
(0.107)\end{array}$ & $\begin{array}{l}-0.229 * * * \\
(0.041)\end{array}$ \\
\hline Size squared & $\begin{array}{l}-0.006^{* * * *} \\
(0.001)\end{array}$ & $\begin{array}{l}0.010 * * * \\
(0.002)\end{array}$ & $\begin{array}{l}0.019 * * * \\
(0.006)\end{array}$ & $\begin{array}{l}0.015 * * * \\
(0.002)\end{array}$ & $\begin{array}{l}-0.005^{* * * *} \\
(0.001)\end{array}$ & $\begin{array}{l}0.017 \\
(0.006)\end{array}$ & $\begin{array}{l}0.010 * * * \\
(0.002)\end{array}$ \\
\hline Market-to-book & $\begin{array}{l}-0.097 * * * \\
(0.003)\end{array}$ & $\begin{array}{l}-0.071 * * \\
(0.028)\end{array}$ & $\begin{array}{l}-0.032 * * * \\
(0.020)\end{array}$ & $\begin{array}{l}0.020 * * \\
(0.008)\end{array}$ & $\begin{array}{l}-0.098^{* * * *} \\
(0.003)\end{array}$ & $\begin{array}{l}-0.108^{* * * *} \\
(0.014)\end{array}$ & $\begin{array}{l}-0.050^{*} \\
(0.026)\end{array}$ \\
\hline Abnormal earnings & $\begin{array}{l}-0.109 * * * \\
(0.015)\end{array}$ & $\begin{array}{l}-0.175^{* * * *} \\
(0.043)\end{array}$ & $\begin{array}{l}-0.767 * * * \\
(0.151)\end{array}$ & $\begin{array}{l}-0.039 \\
(0.024)\end{array}$ & $\begin{array}{l}-0.121 * * * \\
(0.015)\end{array}$ & $\begin{array}{l}-0.852 * * * \\
(0.153)\end{array}$ & $\begin{array}{l}-0.111 * * * \\
(0.042)\end{array}$ \\
\hline Asset maturity & $\begin{array}{l}0.000 \\
(0.000)\end{array}$ & $\begin{array}{l}-0.001 \\
(0.001)\end{array}$ & $\begin{array}{l}0.003 * * \\
(0.001)\end{array}$ & $\begin{array}{l}-0.003 * * * \\
(0.000)\end{array}$ & $\begin{array}{l}-0.001 * * * \\
(0.000)\end{array}$ & $\begin{array}{l}0.009 * * * \\
(0.003)\end{array}$ & $\begin{array}{l}-0.002 * * \\
(0.001)\end{array}$ \\
\hline Asset volatility & $\begin{array}{l}-2.104 * * * \\
(0.097)\end{array}$ & $\begin{array}{l}-1.819 * * * \\
(0.566)\end{array}$ & $\begin{array}{l}-2.877 * * * \\
(0.516)\end{array}$ & $\begin{array}{l}0.143 \\
(0.207)\end{array}$ & $\begin{array}{l}-2.123 * * * \\
(0.103)\end{array}$ & $\begin{array}{l}-4.130 * * * \\
(0.613)\end{array}$ & $\begin{array}{l}-1.183^{* *} \\
(0.535)\end{array}$ \\
\hline Leverage & & $\begin{array}{l}-1.229 * * * \\
(0.269)\end{array}$ & $\begin{array}{l}0.641 * * * \\
(0.141)\end{array}$ & $\begin{array}{l}-0.352 * * * \\
(0.033)\end{array}$ & & & $\begin{array}{l}-1.078^{* * * *} \\
(0.250)\end{array}$ \\
\hline R\&D & $\begin{array}{l}-0.015 \\
(0.046)\end{array}$ & $\begin{array}{l}0.180 \\
(0.113)\end{array}$ & $\begin{array}{l}0.520 * * \\
(0.254)\end{array}$ & $\begin{array}{l}0.222 * * \\
(0.111)\end{array}$ & $\begin{array}{l}-0.014 \\
(0.047)\end{array}$ & $\begin{array}{l}0.244 \\
(0.271)\end{array}$ & $\begin{array}{l}0.163 \\
(0.112)\end{array}$ \\
\hline R\&D dummy & $\begin{array}{l}0.021 * * * \\
(0.005)\end{array}$ & $\begin{array}{l}0.050 * * * \\
(0.013)\end{array}$ & $\begin{array}{l}-0.057 * * \\
(0.277)\end{array}$ & $\begin{array}{l}0.027 * * * \\
(0.009)\end{array}$ & $\begin{array}{l}0.019 * * * \\
(0.005)\end{array}$ & $\begin{array}{l}-0.031 * * \\
(0.028)\end{array}$ & $\begin{array}{l}0.045^{* * * *} \\
(0.012)\end{array}$ \\
\hline Term structure & $\begin{array}{l}1.701 * * * \\
(0.170)\end{array}$ & $\begin{array}{l}3.660 * * * \\
(0.574)\end{array}$ & $\begin{array}{l}3.242 * * * \\
(0.946)\end{array}$ & $\begin{array}{l}2.058 * * * \\
(0.401)\end{array}$ & $\begin{array}{l}1.654 \\
(0.179)\end{array}$ & $\begin{array}{l}3.731 * * * \\
(1.063)\end{array}$ & $\begin{array}{l}2.981 * * * \\
(0.566)\end{array}$ \\
\hline PPE & $\begin{array}{l}0.138 * * * \\
(0.019)\end{array}$ & & & & $\begin{array}{l}0.138 * * \\
(0.019)\end{array}$ & $\begin{array}{l}-0.239 * * \\
(0.116)\end{array}$ & \\
\hline CEO age & & & $\begin{array}{l}0.939 * * * \\
(0.106)\end{array}$ & & & & \\
\hline Ind. med. CEO leverage & & & $\begin{array}{l}0.857 * * * \\
(0.074)\end{array}$ & & $\begin{array}{l}0.035^{* * *} \\
(0.008)\end{array}$ & $\begin{array}{l}0.862 * * * \\
(0.074)\end{array}$ & \\
\hline Constant & $\begin{array}{l}0.107 * \\
(0.063)\end{array}$ & $\begin{array}{l}1.974 * * * \\
(0.142)\end{array}$ & $\begin{array}{l}-1.742 * * * \\
(0.597)\end{array}$ & $\begin{array}{l}1.804 * * * \\
(0.135)\end{array}$ & $\begin{array}{l}0.143 * * \\
(0.064)\end{array}$ & $\begin{array}{l}-2.178 * * * \\
(0.483)\end{array}$ & $\begin{array}{l}1.844 * * * \\
(0.145)\end{array}$ \\
\hline $\begin{array}{l}\text { Observations } \\
F \text {-statistics }\end{array}$ & $\begin{array}{l}4,793 \\
54.46 * * *\end{array}$ & 4,793 & $\begin{array}{l}4,756 \\
112.44 * * *\end{array}$ & 4,756 & $\begin{array}{l}4,793 \\
37.05 * * *\end{array}$ & $\begin{array}{l}4,756 \\
71.85^{* * *}\end{array}$ & 4,793 \\
\hline$J$-statistics & & & & 1.698 & & & \\
\hline
\end{tabular}




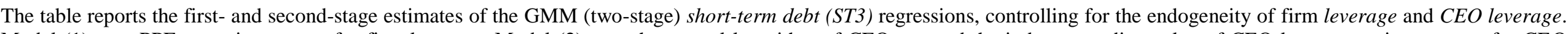

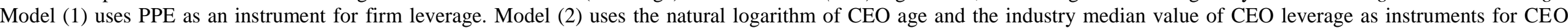

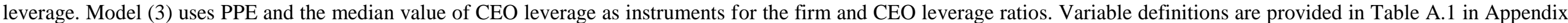

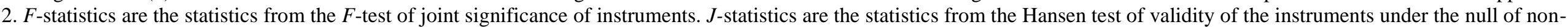

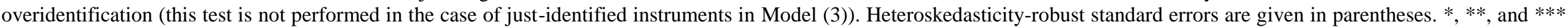
indicate significance of the coefficients at the $10 \%, 5 \%$, and $1 \%$ levels, respectively. 
Table 7. CEO Inside Debt and Short-term Debt: Sub-period Regression Results

\begin{tabular}{|c|c|c|c|c|}
\hline \multirow[t]{2}{*}{ Variable } & \multicolumn{2}{|c|}{$\begin{array}{c}(1) \\
2^{\text {nd }} \text { stage regression }\end{array}$} & \multicolumn{2}{|c|}{$\begin{array}{c}(2) \\
2^{\text {nd }} \text { stage regression }\end{array}$} \\
\hline & $2006-2008$ & $2009-2012$ & $\begin{array}{l}\text { Low Term } \\
\text { Structure }\end{array}$ & $\begin{array}{l}\text { High Term } \\
\text { Structure }\end{array}$ \\
\hline \multirow[t]{2}{*}{ CEO leverage } & $0.049 *$ & $0.055 * * *$ & $0.087 * * *$ & $0.050 * * *$ \\
\hline & $(0.029)$ & $(0.019)$ & $(0.030)$ & $(0.019)$ \\
\hline \multirow[t]{2}{*}{ Size } & $-0.292 * * *$ & $-0.299 * * *$ & $-0.273 * * *$ & $-0.285^{* * *}$ \\
\hline & $(0.043)$ & $(0.041)$ & $(0.048)$ & $(0.038)$ \\
\hline \multirow[t]{2}{*}{ Size squared } & $0.015^{* * *} *$ & $0.014 * * *$ & $0.014 * * *$ & $0.013 * * *$ \\
\hline & $(0.002)$ & $(0.002)$ & $(0.003)$ & $(0.002)$ \\
\hline \multirow[t]{2}{*}{ Market-to-book } & $0.023 *$ & $0.021 *$ & 0.016 & $0.029 * *$ \\
\hline & $(0.012)$ & $(0.011)$ & $(0.012)$ & $(0.011)$ \\
\hline \multirow[t]{2}{*}{ Abnormal earnings } & -0.061 & -0.011 & -0.001 & -0.043 \\
\hline & $(0.040)$ & $(0.036)$ & $(0.051)$ & $(0.028)$ \\
\hline \multirow[t]{2}{*}{ Asset maturity } & $-0.002 * * *$ & $-0.004 * * *$ & $-0.003 * * *$ & $-0.003 * * *$ \\
\hline & $(0.001)$ & $(0.001)$ & $(0.001)$ & $(0.001)$ \\
\hline \multirow[t]{2}{*}{ Asset volatility } & -0.227 & 0.001 & -0.027 & 0.028 \\
\hline & $(0.408)$ & $(0.263)$ & $(0.476)$ & $(0.243)$ \\
\hline \multirow[t]{2}{*}{ Leverage } & $-0.400 * * *$ & $-0.344 * * *$ & $-0.332 * * *$ & $-0.365 * * *$ \\
\hline & $(0.051)$ & $(0.043)$ & $(0.053)$ & $(0.042)$ \\
\hline \multirow[t]{2}{*}{$\mathrm{R} \& \mathrm{D}$} & 0.141 & $0.284^{*}$ & 0.133 & $0.270^{*}$ \\
\hline & $(0.154)$ & $(0.157)$ & $(0.169)$ & $(0.145)$ \\
\hline \multirow[t]{2}{*}{ R\&D dummy } & 0.001 & $0.046 * * *$ & 0.004 & $0.038 * * *$ \\
\hline & $(0.014)$ & $(0.013)$ & $(0.014)$ & $(0.012)$ \\
\hline \multirow[t]{2}{*}{ Term structure } & $3.099 * * *$ & $7.112 * * *$ & $-3.078 * * *$ & 2.105 \\
\hline & (1.024) & $(0.989)$ & $(0.850)$ & (1.409) \\
\hline \multirow[t]{2}{*}{ Constant } & $1.769 * * *$ & $1.683 * * *$ & $1.637 * * *$ & $1.776 * * *$ \\
\hline & $(0.198)$ & $(0.189)$ & $(0.226)$ & $(0.177)$ \\
\hline$F$-statistics & $29.90 * * *$ & $95.70 * * *$ & $45.61 * * *$ & $75.10 * * *$ \\
\hline$J$-statistics & 0.518 & 0.751 & 0.139 & 0.160 \\
\hline Observations & 2,060 & 2,696 & 1,838 & 2,918 \\
\hline Adj. R-squared & 0.131 & 0.147 & 0.078 & 0.147 \\
\hline
\end{tabular}

This table examines the impact of CEO leverage on short-term debt for different time periods. Column 1 reports the second-stage estimates of the GMM (two-stage) regressions of the short-term debt (ST3) model for the subperiods 2006-2008 and 2009-2012. We use the natural logarithm of CEO age and the industry median value of CEO leverage as instruments for CEO leverage in the GMM regressions. Column 2 reports the second-stage GMM estimates for the sub-periods with an above- and below-median term structure of interest rates. Variable definitions are provided in Table A.1 in Appendix 2. F-statistics are the statistics from the $F$-test of joint significance of instruments in the (untabulated) first-stage regressions. $J$-statistics are the statistics from the Hansen test of validity of the instruments under the null of non-overidentification. Heteroskedasticity-robust standard errors are given in parentheses. *, **, and *** indicate significance of the coefficients at the $10 \%, 5 \%$, and $1 \%$ levels, respectively. 
Table 8. CEO Inside Debt and Short-term Debt: Results Conditional on Financial Constraints

\begin{tabular}{|c|c|c|c|c|c|c|c|c|}
\hline \multirow[t]{2}{*}{ Variable } & \multicolumn{2}{|c|}{$\begin{array}{c}(1) \\
2^{\text {nd }} \text { stage regression } \\
\text { SA index }\end{array}$} & \multicolumn{2}{|c|}{$\begin{array}{c}(2) \\
2^{\text {nd }} \text { stage regression } \\
\text { WW index }\end{array}$} & \multicolumn{2}{|c|}{$\begin{array}{c}(3) \\
2^{\text {nd }} \text { stage regression } \\
\text { Dividend }\end{array}$} & \multicolumn{2}{|c|}{$\begin{array}{c}(4) \\
2^{\text {nd }} \text { stage regression } \\
\text { Rating }\end{array}$} \\
\hline & Constrained & Unconstrained & Constrained & Unconstrained & Payers & Non-payers & Non-rated & Rated \\
\hline CEO leverage & $\begin{array}{l}0.042 \\
(0.034)\end{array}$ & $\begin{array}{l}0.046^{* * *} \\
(0.019)\end{array}$ & $\begin{array}{l}0.037 \\
(0.026)\end{array}$ & $\begin{array}{l}0.041 * * \\
(0.018)\end{array}$ & $\begin{array}{l}0.017 \\
(0.048)\end{array}$ & $\begin{array}{l}0.053^{* * * *} \\
(0.017)\end{array}$ & $\begin{array}{l}0.040 \\
(0.051)\end{array}$ & $\begin{array}{l}0.039 * * * \\
(0.014)\end{array}$ \\
\hline Size & $\begin{array}{l}-0.287 * * * \\
(0.039)\end{array}$ & $\begin{array}{l}-0.341 * * * \\
(0.070)\end{array}$ & $\begin{array}{l}-0.100 \\
(0.135)\end{array}$ & $\begin{array}{l}-0.310^{* * * *} \\
(0.081)\end{array}$ & $\begin{array}{l}-0.297 * * * \\
(0.066)\end{array}$ & $\begin{array}{l}-0.328 * * * \\
(0.037)\end{array}$ & $\begin{array}{l}-0.125 \\
(0.107)\end{array}$ & $\begin{array}{l}-0.135^{* * * *} \\
(0.038)\end{array}$ \\
\hline Size squared & $\begin{array}{l}0.014 * * * \\
(0.002)\end{array}$ & $\begin{array}{l}0.017 * * * \\
(0.004)\end{array}$ & $\begin{array}{l}-0.000 \\
(0.009)\end{array}$ & $\begin{array}{l}0.015 * * * \\
(0.004)\end{array}$ & $\begin{array}{l}0.015 * * * \\
(0.004)\end{array}$ & $\begin{array}{l}0.017 * * * \\
(0.002)\end{array}$ & $\begin{array}{l}0.004 \\
(0.007)\end{array}$ & $\begin{array}{l}0.007 * * * \\
(0.002)\end{array}$ \\
\hline Market-to-book & $\begin{array}{l}0.020 * \\
(0.011)\end{array}$ & $\begin{array}{l}0.018 \\
(0.012)\end{array}$ & $\begin{array}{l}0.030 * * \\
(0.014)\end{array}$ & $\begin{array}{l}0.031 * * * \\
(0.012)\end{array}$ & $\begin{array}{l}0.040 * * * \\
(0.015)\end{array}$ & $\begin{array}{l}0.018^{*} \\
(0.009)\end{array}$ & $\begin{array}{l}0.019 \\
(0.016)\end{array}$ & $\begin{array}{l}0.011 \\
(0.008)\end{array}$ \\
\hline Abnormal earnings & $\begin{array}{l}-0.086^{* *} \\
(0.037)\end{array}$ & $\begin{array}{l}0.007 \\
(0.034)\end{array}$ & $\begin{array}{l}-0.102 * * * \\
(0.034)\end{array}$ & $\begin{array}{l}0.028 \\
(0.042)\end{array}$ & $\begin{array}{l}-0.061 \\
(0.039)\end{array}$ & $\begin{array}{l}-0.042 \\
(0.041)\end{array}$ & $\begin{array}{l}-0.147 * * * \\
(0.056)\end{array}$ & $\begin{array}{l}-0.010 \\
(0.024)\end{array}$ \\
\hline Asset maturity & $\begin{array}{l}-0.003 * * * \\
(0.001)\end{array}$ & $\begin{array}{l}-0.003 * * * \\
(0.001)\end{array}$ & $\begin{array}{l}-0.004 * * * \\
(0.001)\end{array}$ & $\begin{array}{l}-0.003 * * * \\
(0.001)\end{array}$ & $\begin{array}{l}-0.002 * * \\
(0.001)\end{array}$ & $\begin{array}{l}-0.003 * * * \\
(0.000)\end{array}$ & $\begin{array}{l}-0.005^{* * * *} \\
(0.001)\end{array}$ & $\begin{array}{l}-0.003 * * * \\
(0.000)\end{array}$ \\
\hline Asset volatility & $\begin{array}{l}0.189 \\
(0.284)\end{array}$ & $\begin{array}{l}0.039 \\
(0.293)\end{array}$ & $\begin{array}{l}0.154 \\
(0.290)\end{array}$ & $\begin{array}{l}0.036 \\
(0.302)\end{array}$ & $\begin{array}{l}-0.286 \\
(0.342)\end{array}$ & $\begin{array}{l}0.257 \\
(0.259)\end{array}$ & $\begin{array}{l}0.770 * \\
(0.403)\end{array}$ & $\begin{array}{l}-0.396^{*} \\
(0.216)\end{array}$ \\
\hline Leverage & $\begin{array}{l}-0.426 * * * \\
(0.047)\end{array}$ & $\begin{array}{l}-0.260 * * * \\
(0.047)\end{array}$ & $\begin{array}{l}-0.478 * * * \\
(0.054)\end{array}$ & $\begin{array}{l}-0.110 * * \\
(0.044)\end{array}$ & $\begin{array}{l}-0.404 * * * \\
(0.075)\end{array}$ & $\begin{array}{l}-0.287 * * * \\
(0.042)\end{array}$ & $\begin{array}{l}-0.502 * * * \\
(0.093)\end{array}$ & $\begin{array}{l}-0.212 * * * \\
(0.033)\end{array}$ \\
\hline $\mathrm{R} \& \mathrm{D}$ & $\begin{array}{l}0.265^{*} \\
(0.141)\end{array}$ & $\begin{array}{l}0.002 \\
(0.176)\end{array}$ & $\begin{array}{l}0.689 * * * \\
(0.193)\end{array}$ & $\begin{array}{l}-0.191 \\
(0.133)\end{array}$ & $\begin{array}{l}0.550 * * * \\
(0.162)\end{array}$ & $\begin{array}{l}-0.438^{* * * *} \\
(0.153)\end{array}$ & $\begin{array}{l}0.506 * * \\
(0.204)\end{array}$ & $\begin{array}{l}-0.140 \\
(0.110)\end{array}$ \\
\hline R\&D dummy & $\begin{array}{l}0.021 \\
(0.014)\end{array}$ & $\begin{array}{l}0.026^{* *} \\
(0.013)\end{array}$ & $\begin{array}{l}0.052 * * * \\
(0.016)\end{array}$ & $\begin{array}{l}0.017 \\
(0.012)\end{array}$ & $\begin{array}{l}0.012 \\
(0.018)\end{array}$ & $\begin{array}{l}0.023 * * \\
(0.011)\end{array}$ & $\begin{array}{l}0.063 * * * \\
(0.022)\end{array}$ & $\begin{array}{l}0.003 \\
(0.010)\end{array}$ \\
\hline Term structure & $\begin{array}{l}3.133 * * * \\
(0.619)\end{array}$ & $\begin{array}{l}1.097 * * \\
(0.514)\end{array}$ & $\begin{array}{l}3.544 * * * \\
(0.779)\end{array}$ & $\begin{array}{l}0.668 \\
(0.587)\end{array}$ & $\begin{array}{l}4.554 * * * \\
(0.756)\end{array}$ & $\begin{array}{l}1.040 * * \\
(0.458)\end{array}$ & $\begin{array}{l}3.832 * * * \\
(0.931)\end{array}$ & $\begin{array}{l}1.217 * * * \\
(0.401)\end{array}$ \\
\hline Constant & $\begin{array}{l}1.749 * * * \\
(0.179)\end{array}$ & $\begin{array}{l}1.975 * * * \\
(0.316)\end{array}$ & $\begin{array}{l}1.118 * * \\
(0.501)\end{array}$ & $\begin{array}{l}1.817 * * * \\
(0.416)\end{array}$ & $\begin{array}{l}1.768 * * * \\
(0.272)\end{array}$ & $\begin{array}{l}1.916 * * * \\
(0.172)\end{array}$ & $\begin{array}{l}1.124 * * * \\
(0.421)\end{array}$ & $\begin{array}{l}0.971 * * * \\
(0.183)\end{array}$ \\
\hline$F$-statistics & $28.37 * * *$ & $63.21 * * *$ & $43.93 * * *$ & $62.59 * * *$ & $25.01 * * *$ & $84.91 * * *$ & $14.40 * * *$ & $101.77 * * *$ \\
\hline$J$-statistics & 1.476 & 0.177 & 0.115 & 0.089 & 0.024 & 1.409 & 0.026 & 0.063 \\
\hline Observations & 2,378 & 2,378 & 1,946 & 1,946 & 1,540 & 3,216 & 1,224 & 3,532 \\
\hline Adj. R-squared & 0.161 & 0.0819 & 0.165 & 0.038 & 0.183 & 0.108 & 0.141 & 0.0346 \\
\hline
\end{tabular}

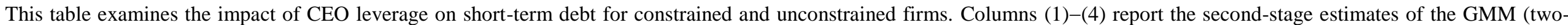

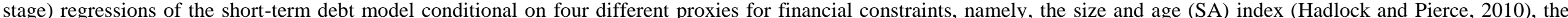

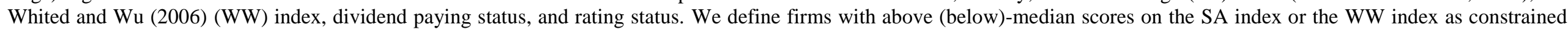

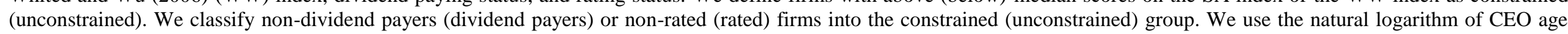

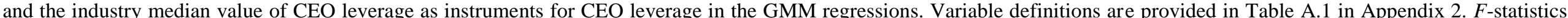

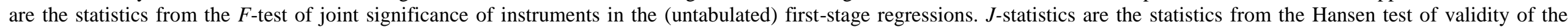

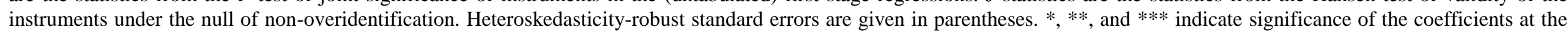
$10 \%, 5 \%$, and $1 \%$ levels, respectively. 
Table 9. CEO Inside Debt and Maturities of New Debt Issues

\begin{tabular}{|c|c|c|c|c|c|c|c|}
\hline Variable & (1) & (2) & (3) & (4) & (5) & (6) & (7) \\
\hline CEO leverage & $\begin{array}{l}-0.090 * * \\
(0.035)\end{array}$ & $\begin{array}{l}-0.084 * * \\
(0.036)\end{array}$ & $\begin{array}{l}-0.092 * * \\
(0.036)\end{array}$ & $\begin{array}{l}-0.086 * * \\
(0.040)\end{array}$ & $\begin{array}{l}-0.091 * * \\
(0.040)\end{array}$ & $\begin{array}{l}-0.101 * * \\
(0.044)\end{array}$ & $\begin{array}{l}-0.102 * * \\
(0.044)\end{array}$ \\
\hline Size & $\begin{array}{l}-0.423 \\
(0.306)\end{array}$ & $\begin{array}{l}-0.393 \\
(0.308)\end{array}$ & $\begin{array}{l}-0.480 \\
(0.306)\end{array}$ & $\begin{array}{l}-0.469 \\
(0.362)\end{array}$ & $\begin{array}{l}-0.526 \\
(0.371)\end{array}$ & $\begin{array}{l}-0.712^{*} \\
(0.408)\end{array}$ & $\begin{array}{l}-0.717^{*} \\
(0.408)\end{array}$ \\
\hline Size squared & $\begin{array}{l}0.014 \\
(0.016)\end{array}$ & $\begin{array}{l}0.013 \\
(0.016)\end{array}$ & $\begin{array}{l}0.017 \\
(0.016)\end{array}$ & $\begin{array}{l}0.014 \\
(0.019)\end{array}$ & $\begin{array}{l}0.016 \\
(0.020)\end{array}$ & $\begin{array}{l}0.026 \\
(0.022)\end{array}$ & $\begin{array}{l}0.026 \\
(0.022)\end{array}$ \\
\hline Market-to-book & $\begin{array}{l}0.151 * * \\
(0.060)\end{array}$ & $\begin{array}{l}0.153 * * \\
(0.061)\end{array}$ & $\begin{array}{l}0.163 * * * \\
(0.059)\end{array}$ & $\begin{array}{l}0.141 * \\
(0.078)\end{array}$ & $\begin{array}{l}0.165 * * \\
(0.080)\end{array}$ & $\begin{array}{l}0.209 * * \\
(0.095)\end{array}$ & $\begin{array}{l}0.210 * * \\
(0.095)\end{array}$ \\
\hline Abnormal earnings & $\begin{array}{l}-0.164 \\
(0.113)\end{array}$ & $\begin{array}{l}-0.161 \\
(0.119)\end{array}$ & $\begin{array}{l}-0.208 * \\
(0.111)\end{array}$ & $\begin{array}{l}0.001 \\
(0.168)\end{array}$ & $\begin{array}{l}0.028 \\
(0.175)\end{array}$ & $\begin{array}{l}0.054 \\
(0.172)\end{array}$ & $\begin{array}{l}0.056 \\
(0.172)\end{array}$ \\
\hline Asset maturity & $\begin{array}{l}0.012 * * * \\
(0.004)\end{array}$ & $\begin{array}{l}0.012 * * * \\
(0.004)\end{array}$ & $\begin{array}{l}0.011 * * * \\
(0.004)\end{array}$ & $\begin{array}{l}-0.003 \\
(0.006)\end{array}$ & $\begin{array}{l}-0.003 \\
(0.006)\end{array}$ & $\begin{array}{l}-0.002 \\
(0.008)\end{array}$ & $\begin{array}{l}-0.001 \\
(0.008)\end{array}$ \\
\hline Asset volatility & $\begin{array}{l}-2.838 * * \\
(1.148)\end{array}$ & $\begin{array}{l}-2.969 * * \\
(1.425)\end{array}$ & $\begin{array}{l}-1.883 \\
(1.156)\end{array}$ & $\begin{array}{l}-4.671 * * * \\
(1.506)\end{array}$ & $\begin{array}{l}-5.812 * * * \\
(2.058)\end{array}$ & $\begin{array}{l}-4.670 * \\
(2.445)\end{array}$ & $\begin{array}{l}-4.726^{*} \\
(2.445)\end{array}$ \\
\hline Leverage & $\begin{array}{l}-0.466 \\
(0.301)\end{array}$ & $\begin{array}{l}-0.470 \\
(0.321)\end{array}$ & $\begin{array}{l}-0.038 \\
(0.345)\end{array}$ & $\begin{array}{l}-0.482 \\
(0.372)\end{array}$ & $\begin{array}{l}-0.056 \\
(0.435)\end{array}$ & $\begin{array}{l}0.023 \\
(0.482)\end{array}$ & $\begin{array}{l}0.019 \\
(0.483)\end{array}$ \\
\hline $\mathrm{R} \& \mathrm{D}$ & $\begin{array}{l}-0.868 \\
(0.774)\end{array}$ & $\begin{array}{l}-0.934 \\
(0.790)\end{array}$ & $\begin{array}{l}-0.451 \\
(0.780)\end{array}$ & $\begin{array}{l}0.415 \\
(0.743)\end{array}$ & $\begin{array}{l}1.221 \\
(0.882)\end{array}$ & $\begin{array}{l}0.953 \\
(0.950)\end{array}$ & $\begin{array}{l}1.010 \\
(0.946)\end{array}$ \\
\hline R\&D dummy & $\begin{array}{l}0.037 \\
(0.099)\end{array}$ & $\begin{array}{l}0.035 \\
(0.099)\end{array}$ & $\begin{array}{l}0.012 \\
(0.098)\end{array}$ & $\begin{array}{l}-0.086 \\
(0.143)\end{array}$ & $\begin{array}{l}-0.132 \\
(0.148)\end{array}$ & $\begin{array}{l}-0.075 \\
(0.171)\end{array}$ & $\begin{array}{l}-0.075 \\
(0.172)\end{array}$ \\
\hline Term structure & $\begin{array}{l}5.906 \\
(4.206)\end{array}$ & $\begin{array}{l}6.172 \\
(7.861)\end{array}$ & $\begin{array}{l}5.461 \\
(4.200)\end{array}$ & $\begin{array}{l}9.552 * * \\
(4.496)\end{array}$ & $\begin{array}{l}5.645 \\
(17.222)\end{array}$ & $\begin{array}{l}11.050 \\
(15.286)\end{array}$ & $\begin{array}{l}11.142 \\
(15.289)\end{array}$ \\
\hline Constant & $\begin{array}{l}4.414 * * * \\
(1.398)\end{array}$ & $\begin{array}{l}4.279 * * * \\
(1.409)\end{array}$ & $\begin{array}{l}4.627 * * * \\
(1.449)\end{array}$ & $\begin{array}{l}5.066 * * * \\
(1.641)\end{array}$ & $\begin{array}{l}5.880 * * * \\
(1.898)\end{array}$ & $\begin{array}{l}5.902 * * * \\
(1.895)\end{array}$ & $\begin{array}{l}3.360 * * \\
(1.608)\end{array}$ \\
\hline Year effects & No & Yes & No & No & Yes & Yes & Yes \\
\hline Industry effects & No & No & No & Yes & Yes & Yes & Yes \\
\hline Issue types & No & No & Yes & No & Yes & Yes & Yes \\
\hline Observations & 367 & 367 & 367 & 367 & 367 & 224 & 224 \\
\hline Adj. R-squared & 0.132 & 0.134 & 0.156 & 0.320 & 0.340 & 0.386 & 0.387 \\
\hline
\end{tabular}

Columns $1-5$ of the table report the OLS estimates of the regressions of the maturities of new debt issues on CEO leverage and the control variables. Column 6 (7) reports the results when the dependent variable is the annual equalweighted (issue-size-weighted) average maturity of multiple debt issues. Variable definitions are provided in Table A.1 in Appendix 2. Heteroskedasticity-robust standard errors are given in parentheses. *, **, and *** indicate significance of the coefficients at the $10 \%, 5 \%$, and $1 \%$ levels, respectively. 
Table 10. Alternative Measures of CEO Inside Debt and Maturities of New Debt Issues

\begin{tabular}{|c|c|c|c|c|c|c|c|}
\hline Variable & (1) & (2) & (3) & (4) & (5) & (6) & $\begin{array}{l}(7) \\
2^{\text {nd }} \text { stage } \\
\text { reg. results }\end{array}$ \\
\hline CEO leverage & & & & $\begin{array}{l}-0.098 * * \\
(0.042)\end{array}$ & $\begin{array}{l}-0.087 * * \\
(0.036)\end{array}$ & $\begin{array}{l}-0.110 * * \\
(0.043)\end{array}$ & $\begin{array}{l}-0.496 \\
(0.199)\end{array}$ \\
\hline CEO pension leverage & $\begin{array}{l}-0.135 * * * \\
(0.047)\end{array}$ & & $\begin{array}{l}-0.135 * * * \\
(0.047)\end{array}$ & & & & \\
\hline CEO def. comp. leverage & & $\begin{array}{l}-0.054 \\
(0.117)\end{array}$ & $\begin{array}{l}-0.001 \\
(0.122)\end{array}$ & & & & \\
\hline CEO delta & & & & $\begin{array}{l}-0.013 \\
(0.053)\end{array}$ & & & \\
\hline CEO vega & & & & $\begin{array}{l}-0.101 * * \\
(0.046)\end{array}$ & & & \\
\hline CEO ownership & & & & & $\begin{array}{l}0.663 \\
(0.945)\end{array}$ & & \\
\hline CFO leverage & & & & & & $\begin{array}{l}0.043 \\
(0.044)\end{array}$ & \\
\hline Size & $\begin{array}{l}-0.377 \\
(0.301)\end{array}$ & $\begin{array}{l}-0.379 \\
(0.312)\end{array}$ & $\begin{array}{l}-0.378 \\
(0.311)\end{array}$ & $\begin{array}{l}-0.015 \\
(0.338)\end{array}$ & $\begin{array}{l}-0.432 \\
(0.308)\end{array}$ & $\begin{array}{l}-0.539 \\
(0.338)\end{array}$ & $\begin{array}{l}-0.733 * * \\
(0.365)\end{array}$ \\
\hline Size squared & $\begin{array}{l}0.011 \\
(0.016)\end{array}$ & $\begin{array}{l}0.012 \\
(0.016)\end{array}$ & $\begin{array}{l}0.011 \\
(0.016)\end{array}$ & $\begin{array}{l}-0.004 \\
(0.017)\end{array}$ & $\begin{array}{l}0.014 \\
(0.016)\end{array}$ & $\begin{array}{l}0.020 \\
(0.018)\end{array}$ & $\begin{array}{l}0.030 \\
(0.019)\end{array}$ \\
\hline Market-to-book & $\begin{array}{l}0.163 * * * \\
(0.060)\end{array}$ & $\begin{array}{l}0.145^{* *} \\
(0.061)\end{array}$ & $\begin{array}{l}0.163 * * * \\
(0.061)\end{array}$ & $\begin{array}{l}-0.011 \\
(0.070)\end{array}$ & $\begin{array}{l}0.154 * * \\
(0.061)\end{array}$ & $\begin{array}{l}0.158 * * \\
(0.066)\end{array}$ & $\begin{array}{l}0.149 * * \\
(0.065)\end{array}$ \\
\hline Abnormal earnings & $\begin{array}{l}-0.155 \\
(0.113)\end{array}$ & $\begin{array}{l}-0.256^{* *} \\
(0.116)\end{array}$ & $\begin{array}{l}-0.156 \\
(0.113)\end{array}$ & $\begin{array}{l}-0.210 \\
(0.135)\end{array}$ & $\begin{array}{l}-0.166 \\
(0.113)\end{array}$ & $\begin{array}{l}-0.223 \\
(0.142)\end{array}$ & $\begin{array}{l}0.335 \\
(0.349)\end{array}$ \\
\hline Asset maturity & $\begin{array}{l}0.012 * * * \\
(0.004)\end{array}$ & $\begin{array}{l}0.011 * * * \\
(0.004)\end{array}$ & $\begin{array}{l}0.012 * * * \\
(0.004)\end{array}$ & $\begin{array}{l}0.012 * * * \\
(0.004)\end{array}$ & $\begin{array}{l}0.012 * * * \\
(0.004)\end{array}$ & $\begin{array}{l}0.012 * * * \\
(0.004)\end{array}$ & $\begin{array}{l}0.016 * * * \\
(0.005)\end{array}$ \\
\hline Asset volatility & $\begin{array}{l}-2.661 * * \\
(1.160)\end{array}$ & $\begin{array}{l}-2.786 * * \\
(1.224)\end{array}$ & $\begin{array}{l}-2.665^{* *} \\
(1.172)\end{array}$ & $\begin{array}{l}-2.775^{* *} \\
(1.290)\end{array}$ & $\begin{array}{l}-2.973 * * \\
(1.160)\end{array}$ & $\begin{array}{l}-2.121 * \\
(1.227)\end{array}$ & $\begin{array}{l}-4.225^{* *} \\
(1.675)\end{array}$ \\
\hline Leverage & $\begin{array}{l}-0.408 \\
(0.303)\end{array}$ & $\begin{array}{l}-0.536^{*} \\
(0.306)\end{array}$ & $\begin{array}{l}-0.408 \\
(0.305)\end{array}$ & $\begin{array}{l}-1.200 * * * \\
(0.352)\end{array}$ & $\begin{array}{l}-0.469 \\
(0.300)\end{array}$ & $\begin{array}{l}-0.303 \\
(0.364)\end{array}$ & $\begin{array}{l}-0.252 \\
(0.424)\end{array}$ \\
\hline $\mathrm{R} \& \mathrm{D}$ & $\begin{array}{l}-0.890 \\
(0.769)\end{array}$ & $\begin{array}{l}-0.984 \\
(0.773)\end{array}$ & $\begin{array}{l}-0.889 \\
(0.772)\end{array}$ & $\begin{array}{l}-0.542 \\
(0.829)\end{array}$ & $\begin{array}{l}-0.859 \\
(0.777)\end{array}$ & $\begin{array}{l}-0.820 \\
(0.818)\end{array}$ & $\begin{array}{l}-0.066 \\
(0.969)\end{array}$ \\
\hline R\&D dummy & $\begin{array}{l}0.038 \\
(0.099)\end{array}$ & $\begin{array}{l}0.025 \\
(0.099)\end{array}$ & $\begin{array}{l}0.038 \\
(0.099)\end{array}$ & $\begin{array}{l}-0.080 \\
(0.108)\end{array}$ & $\begin{array}{l}0.034 \\
(0.100)\end{array}$ & $\begin{array}{l}0.021 \\
(0.106)\end{array}$ & $\begin{array}{l}0.127 \\
(0.103)\end{array}$ \\
\hline Term structure & $\begin{array}{l}5.611 \\
(4.206)\end{array}$ & $\begin{array}{l}5.117 \\
(4.241)\end{array}$ & $\begin{array}{l}5.617 \\
(4.249)\end{array}$ & $\begin{array}{l}9.876^{* *} \\
(4.668)\end{array}$ & $\begin{array}{l}6.021 \\
(4.220)\end{array}$ & $\begin{array}{l}4.747 \\
(4.495)\end{array}$ & $\begin{array}{l}0.122 * * \\
(0.048)\end{array}$ \\
\hline Constant & $\begin{array}{l}4.449 * * * \\
(1.501)\end{array}$ & $\begin{array}{l}4.473 * * * \\
(1.568)\end{array}$ & $\begin{array}{l}4.486 * * * \\
(1.564)\end{array}$ & $\begin{array}{l}3.558 * * \\
(1.665)\end{array}$ & $\begin{array}{l}4.722 * * * \\
(1.525)\end{array}$ & $\begin{array}{l}4.885 * * * \\
(1.557)\end{array}$ & $\begin{array}{l}5.896 * * * \\
(1.669)\end{array}$ \\
\hline $\begin{array}{l}F \text {-statistics } \\
J \text {-statistics }\end{array}$ & & & & & & & $\begin{array}{l}11.75 * * * \\
2.677\end{array}$ \\
\hline Observations & 367 & 367 & 367 & 307 & 367 & 340 & 367 \\
\hline Adj. R-squared & 0.134 & 0.124 & 0.134 & 0.144 & 0.133 & 0.129 & \\
\hline
\end{tabular}

Columns 1-3 of the table report the OLS estimates of the regressions of the maturities of bond issues on alternative measures of CEO leverage, including CEO pension leverage and CEO deferred compensation leverage. Columns 4-6 report the estimates of the regressions, controlling for CEO delta, CEO vega, CEO ownership, and CFO leverage. Column 7 reports the second-stage estimates of the GMM regression, controlling for the endogeneity of CEO leverage. It uses the natural logarithm of CEO age and the industry median value of CEO leverage as instruments for CEO leverage. Variable definitions are provided in Table A.1 in Appendix 2. $F$-statistics are the statistics from the $F$-test of joint significance of instruments in the (untabulated) first-stage regressions. $J$-statistics are the statistics from the Hansen test of validity of the instruments under the null of non-overidentification. Heteroskedasticity-robust standard errors adjusted for firm-level clustering are given in parentheses. $* * *$, and $* * *$ indicate significance of the coefficients at the $10 \%, 5 \%$, and $1 \%$ levels, respectively. 
Table 11. CEO Inside Debt and Cost of Debt

\begin{tabular}{|c|c|c|c|}
\hline Variable & (1) & (2) & (3) \\
\hline \multirow[t]{2}{*}{ Bond maturity } & $0.007 * *$ & $0.007 * * *$ & $0.016 * * *$ \\
\hline & $(0.003)$ & $(0.002)$ & $(0.005)$ \\
\hline \multirow[t]{2}{*}{ CEO leverage } & & $-0.008 * * *$ & $0.037 * *$ \\
\hline & & $(0.002)$ & $(0.019)$ \\
\hline \multirow[t]{2}{*}{ CEO leverage $\times$ Bond maturity } & & & $-0.021 * *$ \\
\hline & & & $(0.009)$ \\
\hline \multirow[t]{2}{*}{ Return std. dev. } & 0.025 & -0.080 & -0.015 \\
\hline & $(0.063)$ & $(0.073)$ & $(0.055)$ \\
\hline \multirow[t]{2}{*}{ Avg. daily returns } & 0.800 & 0.815 & 1.597 \\
\hline & $(1.187)$ & $(1.043)$ & $(0.983)$ \\
\hline \multirow[t]{2}{*}{ Avg. rating } & $-0.001 * * *$ & $-0.001 * * *$ & $-0.001 * * *$ \\
\hline & $(0.000)$ & $(0.000)$ & $(0.000)$ \\
\hline \multirow[t]{2}{*}{ ROS } & 0.000 & -0.002 & -0.001 \\
\hline & $(0.007)$ & $(0.005)$ & $(0.006)$ \\
\hline \multirow[t]{2}{*}{ Leverage } & $0.032 * * *$ & $0.022 * * *$ & $0.029 * * *$ \\
\hline & $(0.008)$ & $(0.007)$ & $(0.007)$ \\
\hline \multirow[t]{2}{*}{ Interest coverage } & 0.006 & $0.010 *$ & 0.008 \\
\hline & $(0.007)$ & $(0.006)$ & $(0.005)$ \\
\hline \multirow[t]{2}{*}{ Issue size } & 0.001 & 0.001 & $0.002 *$ \\
\hline & $(0.001)$ & $(0.001)$ & $(0.001)$ \\
\hline \multirow[t]{2}{*}{ Euro-Treasury spread } & 0.058 & 0.131 & -0.062 \\
\hline & $(0.109)$ & $(0.123)$ & $(0.138)$ \\
\hline \multirow[t]{2}{*}{ Term structure } & 0.002 & 0.103 & $0.368 * *$ \\
\hline & $(0.136)$ & $(0.121)$ & $(0.172)$ \\
\hline \multirow[t]{2}{*}{ Constant } & -0.007 & 0.003 & $-0.033^{*}$ \\
\hline & $(0.011)$ & $(0.009)$ & $(0.017)$ \\
\hline \multirow[t]{3}{*}{$F$-statistics } & $9.40 * * *$ & $7.21 * * *$ & $4.69 * * *$ \\
\hline & & $28.14 * * *$ & $21.78 * * *$ \\
\hline & & & $30.93 * * *$ \\
\hline$J$-statistics & 2.296 & 2.501 & $9.187 *$ \\
\hline Observations & 211 & 211 & 211 \\
\hline
\end{tabular}

Columns 1-3 of the table report the second-stage GMM estimates of the regressions of the bond yield spread on the bond maturity, CEO leverage, bond maturity interacted with CEO leverage, and the control variables. We use firm size and firm size squared as instruments for bond maturity and the natural logarithm of CEO age and the industry median value of CEO leverage as instruments for CEO leverage. Variable definitions are provided in Table A.1 in Appendix 2. $F$-statistics are the statistics from the $F$-test of joint significance of instruments in the (untabulated) first-stage regressions. $J$-statistics are the statistics from the Hansen test of validity of the instruments under the null of non-overidentification. Heteroskedasticity-robust standard errors are given in parentheses. $* * *$, and $* * *$ indicate significance of the coefficients at the $10 \%, 5 \%$, and $1 \%$ levels, respectively. 